\title{
Anatolian Default Accentuation and Its Diachronic Consequences
}

\author{
Anthony D. Yates* \\ University of California, Los Angeles, CA, USA \\ adyates@ucla.edu
}

\begin{abstract}
This paper adduces evidence for and attempts to phonologically motivate a pattern of descriptive "retraction" of surface word accent in the Anatolian languages. It is proposed that the innovative accentual peak (ICTUS) in the relevant forms is due to ANATOLIAN DEFAULT ACCENTUATION, which applies when no constituent morpheme in a prosodic word is lexically specified as accented and assigns ICTUs to its leftmost syllable. Diachronic prosodic change is shown to result from the interaction of various morphophonological developments and the stable operation of this default accentual principle, whose effects in Hittite, Palaic, and Luwian require its reconstruction for Proto-Anatolian. Furthermore, the Anatolian evidence is argued to support Kiparsky and Halle's (1977) reconstruction of the same default principle for Proto-IndoEuropean on the basis of Vedic Sanskrit and Balto-Slavic evidence.
\end{abstract}

\section{Keywords}

Indo-European - Anatolian - Hittite - morphophonology - prosody - historical linguistics - language change

* I would like to acknowledge my deep gratitude to the audience of the 26th Annual UCLA IndoEuropean Conference; to IEL's two anonymous reviewers; and to David Goldstein, Dieter Gunkel, Jesse Lundquist, Ryan Sandell, Sam Zukoff and, above all, Craig Melchert for extensive comments and critical discussion. Naturally, all remaining errors are my own.

(C) ANTHONY D. YATES, 2015 | DOI: 10.1163/22125892-00301002

This is an open access article distributed under the terms of the Creative Commons Attribution-Noncommercial 3.o Unported (CC-BY-NC 3.0) License. 
Over the last thirty-five years, scholarship on Anatolian prosody-e.g. Hart (1980), Carruba (1981), Kimball (1983, 1999), Melchert (1984, 1992a, 1994), and most recently Kloekhorst $(2008,2014 a)$ - has made significant advances in diagnosing the position of the word-level accentual peak (or ICTUS) ${ }^{1}$ primarily on the basis of plene writing (cf. 2.2), and thereby determining how the Anatolian languages continue prosodic patterns inherited from Proto-IndoEuropean (PIE). Relatively little attention, however, has been paid to the synchronic principles of ICTUS assignment in these languages, which has led to difficulty in explaining certain cases where Anatolian seems to depart from inherited patterns.

Such cases constitute the focus of this study, which addresses in particular a pattern of ICTUS "retraction" — viz. a descriptive historical leftward shift in the position of the ICTUS-observable in Hittite and the other Anatolian languages. Some Hittite examples of this phenomenon are given in (1): ${ }^{2}$

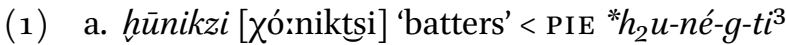

b. nīnikzi [nírnik:tsi] 'mobilizes' < PIE *ni-né-k-ti

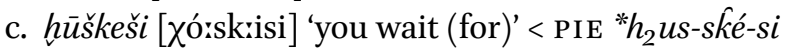

d. punušzi [póznus:tsi] 'interrogates' < PIE "pn(é)u(H)-s-ti

e. teripzi [té(:)rip:tsi] 'plows' < PIE *trép-ti

f. teri- [té(:)ri-] 'three' < PIE *tri-

In all of the forms in (1), preservation of the inherited accentual pattern would have yielded ICTUS on the peninitial syllable; in Hittite, however, the ICTUS is

1 In the sense of Kiparsky (e.g. 2010); cf. 3.1.

2 On the verbal forms in $(1 \mathrm{a}-1 \mathrm{~b})$ and $(1 \mathrm{~d}-1 \mathrm{e})$, see $L I V^{2}$ : s.vv., and further on (1d), cf. Oettinger (1976: 95), Eichner (1978:16o), Kimball (1999:199), and DELG: 852; on (1c), see Puhvel (1991: 410411), who rightly rejects comparison with Hitt. $a u(s)$ - 'see'; and on (1f), see Oettinger (1979:230), Melchert (1994: 84), Kimball (1999: 195-196), and Kloekhorst (2008: 871-872) (pace Kloekhorst (2014b), on which see 2.2 .2 below).

3 Following Kümmel (2007: 227-236), PIE ${ }^{*} h_{1},{ }^{*} h_{2},{ }^{*} h_{3}={ }^{*}[\mathrm{~h}],{ }^{*}[\chi],{ }^{*}[$ в $]$ (cf. Weiss 2014). It is further assumed that these phonetic values were continued into Anatolian, and as such, these symbols are used to represent their Anatolian outcomes in phonetic transcription. For legibility, I depart from standard IPA practice in transcribing [y] for IPA $[\mathrm{j}]$ and $[\hat{\mathrm{g}}, \hat{\mathrm{k}}]$ for the inherited "palatal" velars, as well as using acute accent ['] to mark ICTUs. A right asterisk $\left(X^{*}\right)$ indicates a word that is not directly attested but whose existence is implied by inflectionally or derivationally related forms. Italics denote surface forms throughout; underlying forms are enclosed in slant brackets $(/ /)$. 
realized on the word-initial (or leftmost) syllable. The morphological reconstruction of these forms, the Hittite evidence for their innovative accentuation, the chronology of the relevant developments, and previous scholarship on these problems are discussed further in 2, where it will become clear both that the "retraction" of ICTUS in these forms is linguistically real, and that it has not yet been satisfactorily explained.

Consequently, a new proposal is developed: it is argued that the leftmost ICTUS observable in (1) is derived by the application of ANATOLIAN DEFAULT ACCENTUATION, which is stated informally in (2):

\section{(2) AnAtolian Default accentuation (ADA): ${ }^{4}$}

If a word has no underlyingly accented morpheme, the leftmost syllable bears the ICTUS.

After situating the operation of the ADA in both typological and Indo-European perspective (3.1), it is proposed that accentual change in these (representative) forms results from the interaction of this diachronically stable principle and other Anatolian morphophonological innovations-specifically, new phonotactic constraints and lexical restructuring. A formal implementation of the ADA is developed within the framework of Optimality Theory (Prince and Smolensky 1993/2004). It is thereupon demonstrated that the pre- and postinnovation forms in (1) are not only correctly generated by the hypothesized constraint grammar (3.2), but that the application of ADA to these forms can be motivated on comparative and/or system-internal grounds (4).

More broadly, it is suggested that the Hittite forms in (1) provide diachronic evidence for the operation of ADA in Proto-Anatolian (PA) and its daughter languages. The emergence of the unmarked (or "default") prosodic pattern in these morphologically disparate categories is argued to support this hypothesis, just as similar phenomena in the history of Ancient Greek (cf. 4.2, 5.1-5.2). This proposal, if correct, would inform an increasingly debated issue in Indo-European linguistics, namely, the extent to which ICTUS in PIE was morphologically or phonologically determined. Moreover, it may bear upon theoretical questions of diachronic prosody, e.g.: What are the causes of diachronic prosodic change? How (and why) might the operation of default accentuation in a lexical accent system lead to such effects? The implications of the Anatolian evidence for these questions are considered in 5 .

4 This formulation strongly echoes the Basic Accentuation Principle (Kiparsky and Halle 1977; Kiparsky 2010); see 3.1-3.2 for discussion. 
Determining whether a given form has undergone ICTUs "retraction" depends crucially on synchronic and diachronic considerations - in particular, its morphophonological reconstruction and the attested position of ICTUS. These issues are taken up in 2.1 and 2.2 respectively. The chronology of "retraction" is considered in 2.3. Finally, previous scholarship - and the problems it encounters - are discussed in 2.4 , where the foundation is laid for the alternative approach pursued in this paper.

\subsection{The Historical Basis for Pre-"Retraction" Forms}

The Hittite forms cited in (1) can be divided broadly into two distinct categories: (i) words belonging to morphological categories reconstructed for PIE with non-initial ICTUs; and (ii) words subject to inner-Anatolian epenthesis in the word-initial consonant cluster, causing the historical ICTUs-bearing vowel to be in a non-initial syllable.

(1a) hünikzi and (1b) ninikzi belong to the first of these categories; these examples, along with other nasal-infix verbs in which there is evidence for "retraction," are reproduced in (3): ${ }^{5}$

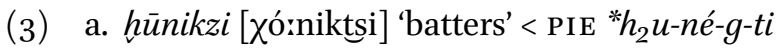

b. nīnikzi [nírnik:tsi] 'mobilizes' < PIE *ni-né-k-ti

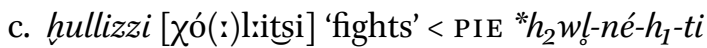

d. zinnizzi [tsí(:)n:itsi] 'finishes' < PIE *ti-né- $h_{1}-t i$

e. dwarnizzi [twárnitsi] 'breaks' < PIE * $d^{h} w_{o}-n e ́-h_{1}-t i$

It is the consensus view that these verbs continue PIE nasal-infix presents, a category that is standardly (though not universally) reconstructed with consistent zero-grade of the root and mobile ICTUS: the strong stem exhibits ICTUS on the full-grade infix, while the weak stem has zero-grade of the infix and ICTUs on the inflectional endings. ${ }^{6}$ The original prosodic behavior of this morphological category is most evident in Vedic Class VII and Class IX presents, e.g. (4):

$5 \quad L I V^{2}$ : s.vv. reconstructs nasal-infix presents for $(3 \mathrm{a}),(3 \mathrm{~b})$, and $(3 \mathrm{~d})$; on $(3 \mathrm{c})$, see Puhvel (1991: 367-368) (cf. Melchert 1994: 65-66; Kloekhorst 2008: 359-36o), and on (3e), Oettinger (1979: 151) (cf. Kloekhorst 2008: 905-908), with the outcome of the syllabic resonant per Kloekhorst (2007) (contra Melchert 1984: 36).

6 Nasal-infix presents correspond to verb class ( $1 \mathrm{k})$ of $L I V^{2}: 38$, which adopts this reconstruction (cf. Clackson 2007: 53-54, Fortson 2010:, etc.); for a dissenting view, see Kloekhorst (2008: 152155) with reff. 
(4) a. Ved. yunákti / yuñjánti 'yoke(s)' (VII) < PIE *yu-né-g-ti / *yu-n-g-énti

b. Ved. punáti / punánti 'cleanse(s)' (IX) < PIE *pu-né- $h_{2}-t i$ / *pu-n- $h_{2}$-énti

In contrast, plene writing of the initial syllable in Hittite $(3 a-3 b)$ unambiguously indicates that the ICTUS falls on this syllable, thus conflicting with the position established for the historical pre-form. While establishing initial ICTUS for $\left(3^{c}-3 \mathrm{e}\right)$ is more difficult, 2.2 presents non-trivial phonological evidence in support of the innovative accentual pattern clearly evident in $(3 a-3 b)$. Nevertheless, the divergent ICTUS of these historical nasal-infix presents has drawn little attention; the conflict has been noted only for ( $3 a)$ and ( $3 b)$, and in neither form explained, likely in part because there is no obvious analogical source for ICTUs "retraction" in such cases.

(1c) hūškeši has undergone a similar historical development. There is general agreement that this verbal stem contains the inherited imperfective suffix *$s k e ́ / o ́-$, whose derivatives regularly bear suffixal ICTUs in Hittite and Vedice.g. (5-6) — and so by assumption, in PIE.

(5) Vedic -c $(c) h$ - $\left(<{ }^{*}\right.$-ské $\left./ o^{-}\right)$presents: ${ }^{7}$

a. rccháti 'reaches' < PIE * $h_{1} r$-ské-ti

b. prcchấmi 'I ask' < PIE *prk̂k-skó(-mi)

(MS I.5.12)

c. ucchási 'you shine' < PIE * $h_{2} u s$-ské-si

(RV I.48.10b)

(6) Hittite -ške-(<*-ské/ó-) presents: ${ }^{8}$

a. daškēmi [təsk:érmi] 'I take' < PIE *d $h_{2}$-sk̂́ó(-mi)

(KBo 17.3 iv 10)

b. akkuškēši [ək:usk:é:si] 'you drink' < PIE * $h_{1 ə} g^{w h_{-s} \hat{k} e ́-s i}$ (KUB 31.143 i 22)

c. zikkēt [tsik:é:t] 'placed' < PIE * $d^{h}{ }_{\partial} h_{1}$-ské-t

(KBo 22.2 Vs 3)

Yet just as in the nasal-infix verbs, it is the verbal root - not the stem-final thematic vowel - that bears ICTUS in (1c), and similarly, the evident "retraction" is unexplained. ${ }^{9}$

7 Cf. $L I V^{2}$ : s.vv. and Mayrhofer (EWA: s.vv.). A few inherited *-ské/ó- verbs have innovated the root ICTUS characteristic of productive Class I presents, e.g. gácchati 'goes' (cf. Gk. $\beta \dot{\alpha} \sigma \kappa \varepsilon l)$.

8 For the root etymologies and attestation of (6), see (e.g.) Kloekhorst (2008: 236-237, 803809 with reff.); on the phonology of (6b) and (synchronically renewed) (6c), see Kavitskaya (2001). The strong stem of Hittite-ške- verbs shows no trace of qualitative ablaut in the suffix, uniformly continuing PIE *-ské- (cf. Yoshida 2010).

9 According to the standard view, the high vowels $* / i /$ and $* / u /$ do not lengthen under the ICTUS in closed syllables (Melchert 1994: 131-133). However, Rieken (2005) and Kloekhorst (2008: 35-60) have now conclusively shown that Hittite has a phonemic distinction between 
The final three forms cited in (1) — viz. (1d) punušzi 'interrogates', (1e) teripzi 'plows', and (1f) teri- 'three' - are morphologically disparate, but phonologically unified: all show the emergence of an epenthetic vowel in the inherited wordinitial obstruent-sonorant cluster, with shift of the ICTUS onto this historically new leftmost syllable. The clearest example of "retraction" in this class is (1d) punušzi, where plene writing of the 1s. pret. pünuššun confirms ICTUS on the first - $u$-vowel, which has developed via epenthesis in the earlier *\#pn-cluster. (1e) and (if) exhibit the same phenomenon, though in these cases ICTUS on the epenthetic $-e$ - vowel in the initial syllable is supported only by indirect diagnostics (cf. 2.2).

Unlike (1a-1c), "retraction" of ICTUS in (1d-1f) has been previously treated (Melchert 1994: 174-175; 2013b: 178-180), yet in such a way that they must be divorced from the other forms that-quite strikingly-appear to show the same prosodic development. These questions are considered in greater detail in 2.4, where a unified approach to "retraction" is advocated; but before proceeding further, it is necessary to examine the Anatolian evidence for the position of the ICTUS.

\subsection{Hittite Evidence for Leftmost ICTUS}

The principal diagnostic for the position of the ICTUS in Hittite is orthographic: scribes employ plene writing - the repetition of identical vowel signs in the spelling of vowels or diphthongs (cf. Kimball 1999: 55) - primarily to mark vowel length, which strongly correlates with ICTUs due to a phonological process lengthening short vowels under the ICTUS. ${ }^{10}$ Thus, if an (etymological) short vowel is written plene, it constitutes prima facie evidence for ICTUS on this vowel.

$/ \mathrm{u} /$ and $/ \mathrm{o} /$, and that one source of the latter is the conditioned lowering of PIE ${ }^{*} u$ next to ${ }^{*} h_{2 / 3}$. If Melchert $(2010)$ is correct that this "new" $/ 0 /$ is also distinguished from $/ \mathrm{u} /$ in Palaic and Luwian, then it is was almost certainly phonologically distinct already in PA; thus it is unproblematic to assume that this lowered vowel did lengthen under the ICTUS in closed syllables, just as the other mid-vowel * $e$ (cf. Melchert 1994: 133, Kloekhorst 2014a: 134) and the "new" /o/ of Hitt. apūn (<a-pu-u-un>) from *óm\#.

10 And conversely, a process that has shortened non-ictic inherited long vowels (cf. Melchert 1994: 76). For plene writing as a marker of vowel length, see (e.g.) Melchert (1994: 27-29), Kimball (1999: 54-58) and Kloekhorst (2014a: 13-19). Melchert (1994: 106-107) assumes that vowel lengthening under the ICTUS-a clear consequence of a highly ranked STRESSto-Weight Principle (cf. Prince 1990)—is a synchronic phonological rule in Hittite, although this issue merits reevaluation; the effects of the rule are discussed by Kimball (1999: 63-64, passim). 
Another important diagnostic for the ICTUS is the development of * $e$. In a significant but often overlooked observation, Melchert (1994: 133) pointed out that in Hittite "inherited short * $[\mathrm{e}]$ is virtually eliminated at the phonetic level." This elimination is effected by a series of conspiratorial phonological processes; besides lengthening under the ICTUS, ${ }^{*} e$ underwent conditioned developments in non-ictic positions: raising to [i] in all pre-tonic syllables and post-tonic closed syllables; and lowering to [a] in post-tonic open syllables. ${ }^{11}$ Accordingly, the $i$ and $a$ outcomes of inherited ${ }^{*} e$ testify (at least) to the relative position of the ICTUS, which in some cases may be the only evidence available.

\subsubsection{PIE Morphological Categories with Non-Initial ICTUS}

As already noted in 2.1, it is possible on the basis of plene writing to establish the position of the ICTUS for two of five historical nasal infix-presents cited in (3) - viz. (3a) hünikzi and (3b) ninikzi-and in addition, the *-ske-form (1c) hūškeši.$^{12}$ (3a) is consistently attested in Old Script (os) texts with plene spelling of the initial syllable-e.g. <hu-u-ni-ik-zi> (KBo 6.2 i 13) —and (3b) once in os $<n i-i-n i-i[k-z] i>$ (KUB 43.31 left col. 10). ${ }^{13}$ (1c) is multiply attested with plene spelling-e.g. 2s. pres. <hu-u-us-ki-si> (KBo 5.13 iii 17-18); 2s. impv. <hu-u-us$k i>($ KBo 5.13 ii 29-30).

More difficult are (3c) hullizzi, (3d) zinnizzi, and (3e) dwarnizzi, which are problematic under all prior analyses. With respect to (3c), Kloekhorst (2008: 359-360) observes a "wide variety" of verbal stems, including hulle/i-, hulla-, and hulliye/a-. The last, attested only in late texts, is a productively derived *-ye/o- formation and so irrelevant to the accentuation of the historical nasal-

11 Per Melchert (1994: 137-139), whose arguments are accepted (e.g.) by Kloekhorst (2008: 97). In post-tonic open syllables, reduction of */e/ to *[ə] may be more accurate.

12 For (1c) and (3a), one must consider the possibility that the spelling HU-U does not mark vowel length (hence ICTUS), but is instead either purely graphic (cf. Kimball 1999: 67-68), or functions to disambiguate between short [o] and [u] (cf. Kloekhorst 2014a: $5^{20-522}$ with reff.). Kloekhorst's (2014a) comprehensive study leads him to conclude that "[e]specially when plene spelling with $\mathrm{U}$ occurs in (nearly) all attestations of a certain word, it is likely that the function of the sign $\mathrm{U}$ was more than just disambiguating $u / o$-ambiguous signs" (ibid.). This criterion clearly supports the linguistic reality of "retraction" in hūni(n)k-, as was noted already by Kimball (1983:484).

13 Kloekhorst (2014a: 427-428) assumes that all (historical) nasal-infix presents in Hittite bear ICTUS on the infix (as in PIE) despite the systematic absence of evidence for plene writing of the infix. The plene writing of nini $(n) k$-is not taken into account by Kloekhorst $(2008,2014 \mathrm{a})$, nor is that of hüni(n)k-, even though the - $u$ - vowel is consistently spelled plene and so meets his own criteria for HU-U signaling vowel length (cf. n. 12 above). 
infix present that is directly reflected in the other two stems. These two stems are fairly well attested in os texts $(8 \times)$, but never with plene writing. In its absence, later spellings with plene writing of the initial syllable-e.g. 3s. pres. $<h u$-u-ul-la-az-zi> (KBo 6.26 ii 11)—offer some support for leftmost ICTUS.

Moreover, assuming leftmost ICTUS may offer insight into the hitherto mysterious fluctuation between hulle/i- and hulla-, which seem to be in free variation. As for hulle/i-, while it is in principle possible to interpret the stem-final vowel as [i] or [e] due to the ambiguity of the sign LI, the [e] reading would require separating this verb from morphologically-identical zinni- and dwarni-, where the [i] is assured..$^{14}$ It is very likely, then, that there are two stems, hulliand hulla-, neither of which can be the phonologically regular outcome of PIE ${ }^{*}$-éh $h_{1} C-{ }^{15}$

If "retraction" of ICTUS in nasal-infix verbs is of PA antiquity (cf. 2.3), then the long vowel in the historical infix that results from loss of tautosyllabic ${ }^{*} h_{1}$ with compensatory lengthening might have subsequently undergone PA shortening of unaccented long vowels. ${ }^{16}$ Under this scenario — schematized in (7) — Hittite would have inherited from PA a strong stem *Húlle-with a final short * [e] vowel, which in turn would yield intraparadigmatic variation between 1st and 2nd vs. 3rd singular forms by the regular operation of Hittite sound laws:

(7) PIE * $h_{2} w \underline{o}-n e ́-h_{1}->$ PA *Húllāe- > *Húlle- > Hitt.

1s. hüllami* 'I fight'

2s. hüllaši* / hullaši

'you fight'

3s. hüllizzi* / hullizzi

'fights'

This distribution is largely maintained in Hittite, where (e.g.) 1s. pret. hullanun $(9 \times)$ is consistently opposed to 3 s. pret. hullit $(9 \times)$. Yet in some cases it breaks down, such as 3 s. pres. huullazzi/hullazzi $(3 \times)$. The stem allomorphy evident in (7) offers a potential explanation for these deviations. Given such intraparadigmatic variation, it is possible that, when the verbal stem ceased to be

14 Melchert (1984: 114); cf. Kloekhorst (2008: 906, 1037).

15 The regular Hittite outcome is $\bar{e}$ [é:], e.g. * ${ }^{h}{ }^{h} h_{1}-t i>$ Hitt. tézzi 'says'; cf. $L I V^{2}: 136-138$. The entirely ad hoc proposal of Kloekhorst (2008: 1037) that the [i] of zinni-results from raising of *ế must be rejected.

16 The relative chronology of laryngeal loss and shortening of long vowels is a vexed question; see the discussion of Kimball (1999: 124-125). The nasal-infix verbs would point to the loss of (at least) coda ${ }^{*} h_{1}$ prior to vowel shortening, thus (partially) supporting the hypothesis of Eichner $(1986,1988)$. 
analyzed as morphologically complex (cf. 4.2.2), some speakers converged on the 1s./2s. singular allomorph hulla- as the underlying form of the verbal base, whence hüllazzi/hullazzi would be inflectionally regular. Yet in this situation, the alternative analysis was also available: the stem allomorph with final [i] may have been reanalyzed by a subset of speakers as the verbal base, thereby leading to new historically "incorrect" forms with $i$-vocalism where $a$-vocalism is expected. ${ }^{17}$ Such a scenario may in fact be reflected in (3d) zinnizzi and $(3 \mathrm{e})$ $d w a r n i z z i$, which show the spread of $i$-vocalism within the verbal paradigm: 1s. pret. zinninun (cf. Oettinger 1979: 311), dwarninun (КUB 41.19 Rs 8); 2s. pres. zinniši (КUB 29.1 i 5 ). 18

In sum, then, the stem-final vowel alternations of $(3 \mathrm{c}),(3 \mathrm{~d})$, and $(3 \mathrm{e})$ are generally consistent with leftmost ICTUS, and provide a possible diachronic source for paradigmatic forms whose vocalism is not lautgesetzlich. For $(3 \mathrm{c})$, these phonological developments corroborate the position of the ICTUS as determined by (late) plene spellings. It is therefore highly probable that all five Hittite nasal-infix verbs in (3) exhibit "retraction" of ICTUs to their leftmost syllable.

This pattern raises the further question of whether nasal-infix presents have systematically undergone "retraction" in Hittite (and PA; cf. 2.2.2). There is neither orthographic nor phonological evidence indicating the position of the ICTUS in the remaining historical nasal-infix presents that preserve mi-verb inflection, Hitt. harnink- 'destroy', ištarnink- 'make sick', or šarnink- 'compensate. The uniformity of "retraction" in those nasal-infix verbs where such diagnostics are available suggests that these verbs too have leftmost ICTUS, but this cannot be confirmed. ${ }^{19}$

\subsubsection{PIE Forms Subject to Anatolian Initial Epenthesis}

"Retraction" is also a feature of (1d) punušzi, (1e) teripzi, and (1f) teri- 'three', all of which show ICTU on the epenthetic vowel that has developed in the PIE wordinitial obstruent-sonorant cluster. As noted in 2.1, this innovative accentual pattern is indicated for (1d) by plene spellings of the initial syllable: (e.g) 1s.

17 In other words, the historically "incorrect" outcomes are analogical to paradigmatic forms with "correct" vocalism.

18 A hapax tuwarnazi (KBo 6.3 i 31) suggests that at least one speaker reached the opposite conclusion, generalizing a stem dwarna-; in a similar vein, zinnami (cf. Oettinger 1979: 311) implies that generalization of zinni- was not universal.

19 In 4.2.2, I contend that these three verbs also underwent demorphologization; whether they preserved the inherited surface accentual pattern or subsequently came under the domain of ADA and received leftmost ICTUS is unclear (cf. $n$. 62 below). 
pret. act. <pu-u-nu-uš-šu-un> (KUB 14.15 ii 12); 3s. pret. act. <pu-u-nu-uš-ta> (KUB 36.35 i 8); and 3pl. pres. act. <pu-ú-nu-uš-ša-an-zi (KUB 20.5 ii 7; O H/Os). ${ }^{20}$

However, plene writing is unattested for (1e) or (1f). Since the sign TE is unambiguous, its consistent use in spelling these forms-e.g. <te-ri-ya-aš> (KUB 43.6o i 9); <te-ri-ip-zi> (VBoT 58 i 30) —and their derivatives must be taken to reflect a real $[e(:)]$ vowel (cf. Melchert 2013a: 139-140). However, while it is generally accepted that this vowel was ICTUs-bearing in (1f) on the strength of its CLuw. correspondent tarriyannalli- 'third-in-command' (cf. 2.3), ${ }^{21}$ the accentuation of (1e) has been disputed by Kloekhorst (2014b: 64-66) on the grounds that "/é/ in an open syllable shows plene spelling in ca. $50 \%$ of its attestations;" he therefore posits a strong stem "/teréptsi/" with peninitial ICTUs.

There are at least two serious objections to this hypothesis. First, it must be recognized that plene writing is fundamentally optional at all periods in Hittite and, in particular, in the later stages of the language. Derivatives of teripp- are first attested only in Middle Script texts, and by far the majority of examples are New Script; ${ }^{22}$ the significance of the absence of plene writing is

20 See $C H D$ (s.v.) for attestation. I assume that epenthesis yielded the mid vowel [o] in labial environments in parallel to its (unconditioned) realization as [e] in (e.g.) teripp- (cf. n. 21, and for "coloring" effects on epenthetic vowels, see Kavitskaya 2001: 288). In this respect, the fluctuation between $\langle u>$ and $<\dot{u}>$ appears problematic; however, in addition to the cited forms, the $<u>$ spelling is attested in ipl. pret. <pu-u-nu-uš-šu-u-en> (AT 454 ii 17 , 21; iv 14; $\mathrm{NH}$ ), and probably also in an incomplete form at KUB 26.17 ii 9, while the only potential parallel for the $\left\langle\dot{u}>\right.$ spelling is partially restored 2pl. pret. $<[p u]-{ }^{\ulcorner} u^{\top}-n u-u s ̌-t e ́ n>$ (KUB $59.10 \mathrm{vi} 2 ; \mathrm{OH} / \mathrm{NS}$ ). In view of the preponderance of $<u>$ spellings, the single assured $<\dot{u}>$ spelling may be attributed to scribal error (rather than a diachronic change, pace Kloekhorst (2008: 682)); for a direct parallel, compare the (similarly os) isolated spelling $<h u$-ú-ni-ik-zi> (кUB 6.2 i 16; о H/OS). I also assume that vowel length in the weak stem is non-original.

21 However, Kloekhorst (2014b) argues that the [e] vowel in teri-is not historically epenthetic but underlying, thus reviving Eichner's (1992: 69) proposal of an inherited "ablaut variant" *ter-i-. This proposal is untenable for reasons cogently stated by Kloekhorst (2008: 872873 ), and the new evidence brought to bear on the issue by Kloekhorst (2014b: 64-65) is non-probative: Lycian trisñni and Milyan trisu may be due to (extensive) languageinternal syncope (which still awaits a full treatment; cf. Melchert 1994: 318-321); similarly, Milyan trpple 'thrice' need not derive from an *i-less *ter-, but could also be the result of syncope (Mil. tbipplẽ 'two-fold' may show only that [r] but not [v] has a syllabic allophone; for preserved pre-tonic \#Cbi-, cf. Mil. Xbidewñne/i-, Lyc. Xbidẽñne/i-< ${ }^{*}$ Xbidéwẽn $\left.(i)-\right)$. All the Anatolian forms are therefore best derived from a generalized weak stem */tri-/ (cf. 4.1.1).

22 Cf. Kimball (1999: 55-57). Kloekhorst (2014a: 183-185, 190-195) presents evidence, specifically, for decreased plene writing of /é/ in open syllables during the $\mathrm{MH} / \mathrm{NH}$ periods. 
thus far from self-evident. Moreover, it remains unclear why the pre-tonic /e/ of a putative "/terépt $\mathrm{t}^{\mathrm{s}} \mathrm{i}$ " - even if epenthesis were properly a post-PA, pre-Hittite phenomenon ${ }^{23}$ - would not have undergone the regular Hittite development of pre-tonic ${ }^{*} e$ to $[\mathrm{i}]$.

In view of these issues, it is preferable to follow Melchert (2013a: 139-140) in the assumption that (1e) teripzi reflects [té(:)rip:tsi] with initial ICTUS and raising of the second ${ }^{*} e$ to [i] in a closed syllable. (1e) thereby reflects the same phenomenon as (1d) punušzi and (1f) teri-, viz. "retraction" of ICTUs to the epenthetic vowel in the historically new leftmost syllable.

\subsection{The Chronology of "Retraction"}

The Hittite forms in (1) and (3) thus bear witness to an accentual change between reconstructed PIE and the earliest attested stage of the language. However, the comparative Anatolian evidence may allow for a more precise determination of the chronology of this development. This point is clearest in the case of (If) teri-, where the geminate -rr- of CLuw. tarri-* 'three'-the implied derivational base of CLuw. tarriyanalli- 'third-in-command'-requires the same pre-form *téri- as its Hittite etymological match. Economy therefore strongly supports the reconstruction of PA *téri- with both vowel epenthesis and ICTUs "retraction," which regularly yields both Hitt. teri- and CLuw. tarri-* via Čop's Law (Čop 1970).

Similar insight into the prehistory of Anatolian nasal-infix verbs is offered by Palaic, where the morphologically-conservative verbal stem šūna- $(<\mathrm{PIE} * / \mathrm{su}-$ né- $\left.\mathrm{h}_{3}-/\right)$ is twice attested, both times with plene of the leftmost syllable: 3 s. pret.

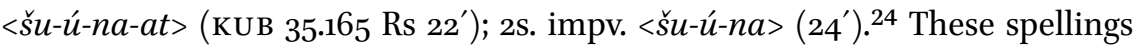
are most plausibly interpreted [súna-] with lengthening of the inherited short " $u$ vowel under the ICTUS, which is "retracted" with respect to its historical position.

23 Kloekhorst (2014b: 65-66) argues for this chronology, but cites as evidence his analysis of the Anatolian evidence for 'three', which I reject (cf. n. 21). However, the possibility that vowel epenthesis in /*\#trV-/ clusters was innovated as a synchronic phonological rule in PA and continued as such into the history of Hittite cannot be discounted (cf. n. 40); this point calls for further investigation.

24 On morphological grounds, the Palaic mi-verb sünat can only be an archaism beside the innovated Hittite hi-verb, which was likely created by analogy to the (ambiguous) 3rd pl. šunnanzi (:: 3rd s. sunnāi), where assimilation is regular (< PIE * su-n- $h_{3}$-ónti; cf. Melchert 1994: 79-80). There is no comparative support for the * ${ }^{*}$ ó- infix posited by Kloekhorst (2008: 785-786); the root-final laryngeal must therefore be ${ }^{*} h_{3}$ (cf. Melchert 1987: 24-25). 
This analysis of Pal. šūna- aligns it with Hittite nasal-infix verbs, the majority of which exhibit direct evidence for leftmost ICTUS. The historical implications of this correspondence are clear: "retraction" of ICTUS in this morphological category is - perhaps even systematically (cf. 2.2.2) — already a feature of PA. And since the same is true of * $t e r i$-, the mechanism responsible for this prosodic change - whatever its precise nature (cf. 3) - should be reconstructed for the PA stage.

\section{$2.4 \quad$ Toward a New Approach}

While ICTUS "retraction" in Anatolian nasal-infix verbs has not previously been addressed, the forms in (1d-1f) with ICTUs-bearing epenthetic vowels fall under the scope of a phonological rule formulated, most explicitly, by Melchert (2013b: 178-179), according to whom "a prehistoric anaptyctic vowel to the left of the original accent regularly drew the accent [= ICTUS] and was thereby lengthened in an open syllable, while a post-tonic anaptyctic vowel remained unaccented [= non-ictic]." If Melchert's proposal is correct, the phonological motivation for "retraction" in these three forms is independent of whatever has caused "retraction" in the nasal-infix verbs, since the latter have etymological underlying vowels, and so cannot be ascribed to the rule's operation. A polygenetic account of ICTUs "retraction" in Anatolian would thus be needed.

It must be acknowledged, however, that there are both empirical and theoretical problems with this rule as formulated. First, there are direct counterexamples to the rule qua historical process, e.g. Hitt. šummittant- 'axe' (< PIE *smit-é/ónt-), as well as a substantial body of synchronic evidence that comes, especially, from Hittite imperfective stems formed with the -ške- suffix. In this productive class, the ICTUS consistently falls on the suffix despite an epenthetic vowel to its left, e.g. (6c) zikkēt 'placed' or azzikkì 'eat!' (KBo 7.28 Rs 18, 23; $\mathrm{OH} / \mathrm{Ms}) ; 25$ this lack of evidence for ICTUS on the anaptyctic vowel constitutes strong evidence against leftward "attraction" of ICTUS as a synchronic rule in the grammar of Hittite, which in turn problematizes its reconstruction for an earlier stage of the language.

To these issues must be added concerns of typological plausibility. Melchert's rule assumes a causal relationship between pre-tonic epenthesis and ICTUS "retraction:" the insertion of an epenthetic vowel would trigger reassignment of the ICTUS. Yet rather than "attract" the ICTUS, epenthetic vowels cross-

25 On the raising of word-final *é to *í, see Melchert (1994: 185) (cf. Kimball 1999: 160, Kloekhorst 2008: 96). 
linguistically are frequently "invisible" to processes like ICTUS assignment (cf. Hall 2011: 1586); and when they do they bear ICTUS, they do so not by virtue of being epenthetic, but because they occupy a position where ICTUS is assigned by a predictable phonological algorithm. ${ }^{26}$

These problems recommend an alternative approach to "retraction" in $(1 \mathrm{~d}-$ 1f). ${ }^{27} \mathrm{~A}$ potential way forward is offered by the nasal-infix verbs, as they confirm the existence of some not fully understood phonological process responsible for assigning ICTUS to the leftmost syllable of a prosodic word. On purely formal grounds, the leftmost ICTUs evident in (1d-1f) is explicable in terms of such a process, which would thereby allow for a unified analysis of ICTUs "retraction." This economical approach is pursued in 3 , where it is argued that the process responsible for assigning leftmost ICTUS to the forms in both (1) and (3) is, specifically, (2) ANATOLIAN DEFAULT ACCENTUATION.

\section{3} The Operation of Anatolian Default Accentuation

In this section, the prosodic typology of PIE is briefly discussed (3.1). The ADA is reintroduced and formalized in a constraint-based framework (3.2), and it is demonstrated that this constraint grammar will correctly generate the attested forms with "retraction" of the ICTUS (3.3).

\subsection{PIE Prosody in Typological Perspective}

The primacy of morphology in determining the position of the single surface accentual peak in PIE words is an assumption shared by all Indo-Europeanists. ${ }^{28}$ This assumption is central to the system of paradigmatic classes, each of which is intended to describe the distribution of this accentual peak within the inflectional paradigm of a word belonging to that paradigmatic class, and also holds for thematic formations. ${ }^{29}$ In the basic typology of prosodic systems, it

$26 \quad$ Like the Classical Latin "antepenultimate rule," on which see Mester (1994).

27 The possibility of a causal connection between epenthesis and ICTUs "retraction" is comprehensively assessed by Yates (forthcoming).

28 For the strongest form of this claim, see (e.g.) Weiss (2011: 106-107): "In Proto-IndoEuropean accent was morphologically determined."

29 While the "kinetic" paradigms posited by Schindler (1972, 1975b, 1975a) and the "Erlangen School" (see esp. Rix 1992) and the "dynamic" paradigms of the "Leiden school" (Beekes 1985; cf. Pedersen 1926; Kuiper 1942; Kloekhorst 2013) differ terminologically and in the details of each class's reconstruction, they both share the basic premise that ICTUS in PIE was morphologically determined. 
may therefore be assumed that PIE had what is generally referred to as a lexical accent system. ${ }^{30}$

Generative analyses of lexical accent systems standardly link the position of the accentual peak in a given morphological category to the prosodic properties of the morpheme(s) instantiating that category. ${ }^{31}$ These properties are listed in a morpheme's lexical entry, which at its most basic level includes whether or not the morpheme is specified for prosodic prominence. In general, the (single) accentual peak will coincide with a morpheme lexically specified for prominence, yet since morphologically complex words may contain multiple such morphemes, the relation between surface accentual peak and underlying prominence is not one-to-one. In analyzing these systems, it is therefore useful to follow Kiparsky (2010, forthcoming) in distinguishing between accent-viz. underlying specification of a morpheme for prosodic prominence that may or may not be realized on the surface-and ICTUs, the surface accentual peak itself. ${ }^{32}$ When multiple accented morphemes are present, languagespecific phonological principles then operate to designate which underlying accent will surface as ICTUS. A word's ICTUS is therefore determined by a phonological computation over the lexical properties of its constituent morphemes, a feature which suggests that such prosodic systems-including the one reconstructed for PIE- are more accurately labelled lexical "interface systems" (cf. Revithiadou 1999: 14-25).

Interface systems of this kind are found in a number of the world's languages. One such language is Cupeño, a Uto-Aztecan language spoken until recently in the vicinity of northern San Diego County. ${ }^{33}$ The Cupeño forms in (8) illustrate

For a (brief) cogent discussion of the PIE prosodic system and "lexical accent," see Kim (2013), and on lexical accent systems generally, Revithiadou (1999).

In this vein, Kiparsky $(1967,1973,1982,1984,2003,2010$, forthcoming) has advocated a "compositional" approach to PIE accentology in contrast to traditional paradigmatic approaches (cf. n. 29); for references to other analyses of ancient IE languages employing compositional principles, see Kiparsky (2010: 137 n. 1).

This terminology has the great benefit of abstracting away from the (separate) issue of the phonetic realization of the ICTUS in the individual languages, thereby facilitating comparison between the tonal systems of (e.g.) Greek and Indo-Iranian and the stressbased system of (e.g.) Germanic.

The last speaker of Cupeño died in 1987; for extensive discussion of the history of the people and their language, see Hill (2005: Chap. 1). Other languages with lexical interface systems include Russian (e.g. Halle 1973; Halle and Kiparsky 1979), Lithuanian (Blevins 1993), Japanese (Poser 1984), Choguita Rarámuri (Caballero 2011), Modern Greek, and Thompson Salish (Revithiadou 1999). The fact that Indo-European languages are so wellrepresented in this list can hardly be coincidental; rather, their prosodic systems must reflect inheritance from PIE (cf. 5.3). 
another important feature common to lexical interface systems, viz. a principle of phonological default accentuation that applies when a word contains no accented morphemes; in this situation, the default principle functions to assign ICTUS in accordance with the strict requirement that every prosodic word be ICTUS-bearing. In Cupeño, the ICTUS is assigned by default to the leftmost syllable: ${ }^{34}$
a. $/ y a x-\partial m / \rightarrow \quad y a ́ x-\partial m$ 'Say!'
b. $/ \mathrm{max}-ə \mathrm{~m} / \rightarrow$ máx-əm 'Give!'
c. /wən - əm/ $\rightarrow$ wán-əm 'Put (it) in'

$$
\begin{array}{r}
(\text { 'say' + IMP.PL) } \\
(\text { 'give' + IMP.PL) } \\
(\text { 'put in' + IMP.PL) }
\end{array}
$$

The role of phonology both in adjudicating between multiple underlying accents and, in their absence, determining default prosodic structure in Cupeño and other languages with lexical interface systems strongly suggests that PIE also had phonological principles governing the distribution of the ICTUS in such situations. Precisely this claim has been made by Kiparsky and Halle (1977), who argue that the phonological mechanism responsible in PIE was the BASIC ACCENTUATION PRINCIPLE in (9):

(9) BASIC ACCENTUATION PRINCIPLE (BAP)::35

If a word has more than one accented syllable, the leftmost of these gets the ICTUS. If a word has no accented syllable, the leftmost syllable gets the ICTUS.

The consequences of this principle-including its default component-are perhaps most transparent in Vedic Sanskrit. It is an important virtue of the Kiparskyan hypothesis that it accounts synchronically for the Vedic distinction between root nouns exhibiting fixed root ICTUS and "mobile" root nouns whose ICTUS shifts from the root in the strong cases to the inflectional endings in the weak cases. This distinction falls out from the assumption that the root is inherently accented in the type with fixed ICTUS (e.g. /gáv-/ 'cow'), while the root is unaccented in the "mobile" type (/nāv-/ 'boat'). Schematic derivations for these two contrasting types are presented in $(10):{ }^{36}$

34 For this analysis of (8), see Alderete (2001b: 472); cf. Hill (2005).

35 This formulation is based on Kiparsky and Halle (1977: 209) and Kiparsky (2010: 6).

36 Kiparsky (2010: 142-143) has proposed that the PIE nominative plural suffix *-es was "preaccenting", i.e. places an accent on the final vowel of the stem to which it attaches (similarly, the singular verb endings discussed in 3.3; cf. Kiparsky (forthcoming)). Since the preaccenting and unaccented analyses make essentially the same predictions in 
(10) Strong (nom.pl.): Ved. /gáv - as/ $\rightarrow$ gáa vaḥ 'cows' vs. Ved. /nāv - as/ $\rightarrow$ ná̀vah 'boats'

Weak (gen.s.): Ved. /gáv - ás/ $\rightarrow$ gávah vs. Ved. /nāv - ás/ $\rightarrow$ nāváh

The effect of the default component of the BAP is apparent in the strong stem of 'boat': since neither the root /nāv-/ nor the plural ending /-as/ is accented, ICTUS is assigned to the leftmost syllable, yielding the surface form Ved.návah.

The central hypothesis of this paper is that a similar principle of default accentuation obtained in the Anatolian languages, and that this principle is responsible for the historically "retracted" ICTUS of the forms cited in (1) and (3). The Cupeño and Vedic evidence in (8) and (10) converge in their support of left edge default ICTUS assignment as a possible feature of lexical interface systems; thus even independent of the question of inheritance, typological considerations lend support to the possibility that (2) ANATOLIAN DEFAULT ACCENTUATION-introduced in 1 and for convenience repeated below-is the root cause of the innovative pattern of leftmost ICTUS observed in Hittite and reconstructible for $\mathrm{PA}$ :

\section{(2) ANATOLian DEFAUlt accentuation (ADA):}

If a word has no underlyingly accented morpheme, the leftmost syllable bears the ictus.

The inheritance question is taken up separately in 5.3; the remainder of this section develops a constraint-based formal implementation of ADA and shows that the Anatolian forms exhibiting ICTU s "retraction" are formally consistent with the operation of ADA.

\subsection{Formalizing ADA: A Constraint-Based Approach}

In lexical interface systems, surface accentual patterns are determined by a complex interplay between morphology and phonology, including default phonological principles like ADA. Such morphophonological interactions are ideally suited for implementation in Optimality Theory (от) (Prince and Smolensky 1993/2004), which can model the (virtual) competition between underlying accent(s) and default accentuation to surface as the single ICTUS. Synchronically, this competition has a consistent winner: ${ }^{37}$ the morphologically depen-

the examples considered here, and at present I know of no independent evidence for preaccentuation in Anatolian, I provisionally treat these suffixes as unaccented (cf. n. 63). 
dent prosodic system Anatolian has inherited from PIE always prefers lexical accent. Thus in accordance with the ADA, default leftmost ICTUS emerges only in the absence of underlyingly accented morphemes.

Within an ot framework, this pattern can be understood as the consequence of prosodic requirements imposed by the two constraints in (11-12):

(11) ALIGN-L(PROM, $\omega$ ) (ALIGN-L): The ICTUS must be aligned with the left edge of a prosodic word. Assign one violation $\left({ }^{*}\right)$ for each syllable between the ICTUS and the word's left edge.

(12) CUlminativity (CULM): A prosodic word must bear exactly one ICTUs.

An inviolable constraint governing prosodic well-formedness, (12) CULMINATIVITY enforces the requirement that all content words in Anatolian be ICTUSbearing. ${ }^{38}$ When no accent is present underlyingly, this requirement is fulfilled by insertion of an accent between input and output representations; (11) ALIGN-L then dictates the syllable on which this accent is realized, preferring the candidate that has the ICTUS aligned with its left edge.

While necessary to satisfy (12) CULMINATIVITY, the insertion of a default accent violates a highly ranked prosodic faithfulness constraint. The domination of (11) ALIG N-L by (13) PROS-FAITH - a cover term for the constraint family in $(13 \mathrm{a}-13 \mathrm{c})$ - ensures that lexically specified accent will regularly surface as ICTUS, thereby blocking the application of ADA: ${ }^{39}$

(13) PROSODIC FAITHFULNESS (PROS-FAITH):

a. MAX-PROM: Every prominence in the input must have a correspondent in the output.

b. DEP-PROM: Every prominence in the output must have a correspondent in the input.

c. NO-FLOP-PROM: Corresponding prominences must have corresponding sponsors and links.

38 On "culminativity" and its related parameter "obligatoriness" as features of prosodic systems, see Hyman (2006).

39 (13) thus equally assesses violations for (13a) deletion, (13b) insertion, and (13c) reassociation of underlying accents, i.e. if an accent were realized as ICTUS on a syllable other than the one with which it is associated underlyingly. On the details of these constraints, see Alderete (2001a: 23-25) (cf. McCarthy 1997). For ease of exposition, neither output candidates with violations of (13c) nor harmonically bounded candidates are considered in the tableaux presented in this paper. 
In terms of the analysis developed here, an underlying accent is an input prominence, while the ICTUS is the output correspondent of an accent.

The constraint ranking in (14) generates the desired accentual pattern: a lexical accent will surface, otherwise ADA assigns default leftmost ICTUS.

\section{(14) CULMINATIVITY $\gg$ PROS-FAITH $\gg$ ALIGN-L}

Its predictions may be illustrated using the Vedic data already presented in (10) above. A mobile root noun like Vedic /nāv-/ 'boat' has ICTUS alternating between the root in the strong cases (e.g. nom. pl. návah) and inflectional endings in the weak cases (gen. s. nāváh). These alternations are correctly produced by the ranking in (14), as the tableaux in (15a) and (15b) confirm:

(15) a. Ved. /nāv - as/ $\rightarrow$ návah 'boats' (nom.pl.)(via BAP default)

\begin{tabular}{|lr||c|c|c|}
\hline \multicolumn{2}{|c||}{$/$ nāv - as/ } & Culm & Pros-Faith & Align-L \\
\hline \hline a. nāvạ̣ & $* !$ & & \\
\hline b. nāváh & & $*$ & $* !$ \\
\hline c. $\rightarrow \quad$ návạ̣ & & $*$ & \\
\hline
\end{tabular}

b. Ved. /nāv - ás/ $\rightarrow$ nāváh 'boat' (gen.s.)

\begin{tabular}{|cr||c|c|c|}
\hline \multicolumn{2}{|c||}{$/$ nāv - ás/ } & Culm & PRos-Faith & AligN-L \\
\hline \hline a. & nāvah & $* !$ & $*$ & \\
\hline b. $\rightarrow$ nāváh & & & $*$ \\
\hline c. & návaḥ & & $* ! *$ & \\
\hline
\end{tabular}

With this apparatus in place, it is now possible to turn to the analysis of the Anatolian evidence for "retraction" of ICTUS.

\subsection{Applying ADA: The Anatolian Data}

From a synchronic perspective, ADA offers a potential explanation for the prosody of Anatolian lexical items that have word-initial ICTUS. In some words, this accentual pattern may be listed in the lexicon as a property of one or more of its constituent morphemes; in others-specifically, those whose underlying form contains no accented morphemes - the leftmost ICTUS will be due to the ADA. Under the assumption that both the Hittite forms subject to inner- 
Anatolian epenthesis in (1) - i.e. (1d) punušzi, (1e) teripzi, and (1f) teri- 'three'and the nasal-infix verbs in (3) (as well as Palaic sūnat and (1c) Hitt. hūuške-) had the PA underlying representations in (16), their leftmost ICTUs follows straightforwardly from the application of ADA: ${ }^{40}$

$$
\begin{aligned}
& (16) * / p n(e) \text { uss - / 'interrogate' */sunō - / 'fill' } \\
& \text { */trep - / 'plow' */tinæ - / 'finish' } \\
& \text { */tri - / 'three' */durnæ - / 'break' } \\
& \text { */Huneg - / 'batter' */Hullæ - / 'fight' } \\
& \text { */ninek - / 'mobilize' */Huske - / 'wait' }
\end{aligned}
$$

Provided with these inputs, the constraint grammar predicts forms at the PA stage that will correctly develop into their observed outcomes in the Anatolian languages. These predictions are exemplified for (1b) and (1e) in the tableaux

\begin{tabular}{|c|c|c|c|c|}
\hline \multicolumn{2}{|c|}{$* /$ ninek $-\mathrm{ti} /$} & Culm & Pros-FAITH & ALIGN-L \\
\hline a. & *ninekti & $* !$ & & \\
\hline b. $\rightarrow$ & *nínekti & & $*$ & \\
\hline c. & *ninékti & & $*$ & $* !$ \\
\hline
\end{tabular}
in (17) and (18) respectively, but the same holds for the rest of the forms in (16).

(17) a. $\quad \mathrm{PA}^{*} /$ ninek $-\mathrm{ti} / \rightarrow$ "nínekti > Hitt. ninnikzi [nínik:tsi] 'mobilizes'

\begin{tabular}{|c|c|c|c|c|}
\hline \multicolumn{2}{|c|}{$* /$ trep - ti $/$} & Culm & PROS-FAITH & Align-L \\
\hline a. & *terepti & $* !$ & & \\
\hline b. $\rightarrow$ & *térepti & & $*$ & \\
\hline c. & *terépti & & $*$ & $* !$ \\
\hline
\end{tabular}

b.

(18) a. $\quad \mathrm{PA}^{*} /$ trep - ti $\rightarrow{ }^{*}$ térepti > Hitt. teripzi [té(:)rip:tsi] 'plows'

b.

40 For */trep-/ and */tri-/ (cf. n. 21), it is trivially assumed that epenthesis is a synchronic phenomenon in PA driven by the emergence of a phonotactic constraint against complex *[tr-] onsets (in OT terms, ${ }^{*}$ [.tr] \ DEP-V; cf. n. 23); the ICTUS of the output forms would be identical if the epenthetic vowel had become underlying. The same is true of */pneuss/; whether or not epenthesis is post-PA, ADA will assign default leftmost ICTUS to the epenthetic vowel. 
However, it is clear that the output of the grammar crucially depends on its inputs - viz. the underlying forms over which it operates - and it is far from trivial to assume that the underlying representations in (16) are correct for the Proto-Anatolian stage. This claim appears particularly problematic in the case of the nasal-infix verbs: rather than the unaccented, monomorphemic stem presented in (16), nasal-infix presents were productively derived in PIE by infixation of /-né-/. Similarly for (1c) huüške-, the PIE form was derived by suffixation of */-ské-l, and in this instance, both the productivity of the derivational process and the morpheme's accentual properties are transparently stable going into and throughout the history of Hittite.

Thus if ADA is indeed the cause of ICTUS "retraction" in the surface forms corresponding to the morphemes in (16), the pressing question is how and why these morphemes came to behave as simplex, unaccented stems, and so fall under the domain of ADA. 4 addresses this question.

This section attempts to motivate the application of ADA to the Anatolian forms discussed in 2.2 that show "retraction" of ICTUS with respect to their PIE forms. It is argued that the forms in question have undergone innovations other than the shift of the ICTUS itself, and that these phonological and/or morphological innovations in conjunction with the ADA trigger the diachronic development of leftmost ICTUS. In 2.2, these forms were divided broadly into two categories, namely, those belonging to morphological categories reconstructed for PIE with non-initial ictus (2.2.1), and those subject to Anatolian vowel epenthesis within a word-initial complex onset (2.2.2). It will become clear in 4.1-4.2 that this basic division maps onto the separate rationale for the application of ADA in each category, although intra-category morphological differences will necessitate some further subdivision. Epenthesis forms are discussed first in 4.1, followed by the more complex morphological formations in 4.2 .

\subsection{Unaccented Roots in PA and ADA}

(1d) Hitt. punušzi, (1e) teripzi, and (1f) teri- are manifestly united by phonological developments, namely, vowel epenthesis and "retraction" of ICтUs to the historically new leftmost syllable. Yet there may also be less obvious commonalities: in 4.1.1 and 4.1.2, it is argued that all three are derived from unaccented roots whose lexical properties remain stable even when new Anatolian phonotactic constraints trigger vowel epenthesis, thus altering the phonolog- 
ical shape of the roots and their derivatives. These phonotactic constraints interact transparently with (11) ALIGN-L — the constraint driving ADA — to yield ICTUS on the newly emergent leftmost syllable. In 4.1.1, comparative evidence supporting the unaccented status of $\mathrm{PA}$ */tri-/ is presented; 4.1.2 contends that $\mathrm{PA} * /$ trep-/ and */pn(e)uss-/ are unaccented on system-internal grounds.

\subsection{1 $\quad \mathrm{PA}$ */tri-/ in Comparative Perspective}

Compelling evidence for an unaccented root PA */tri-/ 'three' comes from comparison with Vedic, where the relatively rich accentual data offers insight into the prosodic properties of this morpheme. In Vedic, the word for 'three' has a mobile paradigm identical to that of /nāv-/ 'boat' (in contrast to /gáv-/ 'cow'; cf. 3.1): nom.pl. tráyah; instr. tribhíh; loc. trișú ${ }^{41}$ And just as for /nāv-/ in (15), the constraint grammar developed in 3.2 correctly generates the mappings in (19) with default ICTUS assignment in the nominative, and lexical accent surfacing in the oblique cases:

(19) Ved. /tray-as/ $\rightarrow$ tráyaḥ 'three'

$$
\begin{aligned}
& \text { /tray-bhís/ } \rightarrow \text { tribhịh } \\
& \text { /tray-sú/ } \rightarrow \text { trișú }
\end{aligned}
$$

The Vedic facts thus support the reconstruction of an unaccented PIE root */trey-/ that is directly continued in PA */tri-/. The inheritance of this unaccented root in turn explains the attested Hittite forms-e.g. 3 -i-e-eš (KU B 10.55, 12) and 3-e-eš (KBo 17.58 i $5 ; \mathrm{OH} / \mathrm{Os}$ ) point to a nominative plural [té(:)riyes], which may be derived via ADA from a Hittite underlying representation $/ \mathrm{t}(\mathrm{e}) \mathrm{ri}-$ es $/ .42$

\subsubsection{The Accentuation of Simplex $m i$-Verbs in PA}

Morphologically, Hittite pünušš- and teripp-both belong to the category of Anatolian simplex $m i$-verbs-i.e. primary root formations - which also includes

41 The unaccentedness of /tray-/ 'three' in Vedic is also evident in compounding-(e.g.) in the contrast between tri-cakrá- 'three-wheeled' (e.g. RV I.157.3a) with ICTUS on the second member and saptá-cakra- 'seven-wheeled' (RV I.164.3b) with ICTUS on the first. In the latter, the lexical accent of the first member (/saptá/) is assigned ICTUs via the BAP because it is the leftmost accent, while in the former, the first member is unaccented (/tray-/), thus allowing the lexical accent of the second member (/cak - rá-/) to receive the ICTUS.

42 On the phonological interpretation of the nominative plural suffix in Hittite, see Kloekhorst (2012). 
verbal roots at the very core of the lexicon such as */es-/ 'be', */ed-/ 'eat', and */gwen-/ 'kill'. Verbs in this category exhibit regular alternations between root ICTUS in the strong stem (singular) and ICTUS on the inflectional endings in the weak (plural). ${ }^{43}$ In this respect, their prosodic behavior is identical to that of Vedic mobile root nouns, a parallelism which suggests the possibility that alternating ICTUS in these verbs is similarly due to the accentual properties of their roots. If these roots are unaccented, the grammar predicts default ICTUS in the singular, while in the plural the inherent accent of the inflectional endings will surface. This pattern is illustrated for the Hittite outcomes of */es-/ 'be' in the strong stem $(20)$ vs. weak stem $(21):{ }^{44}$

(20) a. $\quad \mathrm{PA}^{*} / \mathrm{es}-\mathrm{ti} / \rightarrow$ *ésti > Hitt. èšzi [éststsi]

b.

\begin{tabular}{|c||l|l|l|}
\hline$* /$ es $-\mathrm{ti} /$ & Culm & Pros-Faith & Align-L \\
\hline
\end{tabular}

\begin{tabular}{|lr||c|c|c|}
\hline \hline a. & ${ }^{*}$ esti & $* !$ & & \\
\hline b. $\rightarrow \quad{ }^{*}$ ésti & & $*$ & \\
\hline c. restí & & $*$ & $* !$ \\
\hline
\end{tabular}

(21) a. PA */es - énti $\rightarrow{ }^{*}$ *asénti > Hitt. ašanzi [əsántși]

b.

\begin{tabular}{|lr||c|c|c|}
\hline \multicolumn{2}{|c|}{$*$ es - énti/ } & CUlm & Pros-Faith & Align-L \\
\hline \hline a. $\quad{ }^{*}$ asenti & $* !$ & $*$ & \\
\hline b. $\quad \rightarrow \quad{ }^{*}$ asénti & & & $*$ \\
\hline c. $\quad{ }^{*}$ ásenti & & $*$ * & \\
\hline
\end{tabular}

The prosodic behavior of $\mathrm{PA}^{*}$ /es-/ and other verbs of this type is therefore consistent with the hypothesis that they are categorically derived from unaccented roots. If correct, it would follow that Hittite pünušs- and teripp-are respectively based on the unaccented PA roots */pn(e)uss-/ and */trep-/ posited in (16); and as demonstrated in 3.3-explicitly for teripp-in (18) - the attested strong stem

43 Per Melchert (2013a: 139-40), the pre-Hittite ablaut *téripp-/*tarp- was eliminated by analogical introduction of the strong stem into the plural (including fixed root ICTUS), a well-established response to irregular allomorphy. The alternative scenario of Kloekhorst (2014b: 65-66, 71), in which speakers replace a marked pattern with an entirely unattested one ("trép-/trip-), is implausible.

44 For a possible explanation of the root $a$-vocalism in the weak stem of Hittite verbs like ašanzi, see now Yates (2014) (pace Melchert, 1994: 66-67). 
forms are consistent with the application of ADA: in the absence of underlyingly accented morphemes, the grammar will assign default leftmost ICTUs to (1d) punušzi and (1e) teripzi. ${ }^{45}$

\section{2 "Demorphologization" in PA and ADA}

The relationship between ADA and the Anatolian nasal-infix verbs in (3) as well as Hitt. hūške- must be explained otherwise. Historically, these forms all belong to morphological categories reconstructed for PIE with non-initial ICTUS (cf. 2.2.1), but have developed initial ICTUS in PA or the immediate prehistory of Hittite. It is argued that this prosodic development is the result of two morphophonological innovations: (i) the loss of morphological complexityor "demorphologization" (cf. Probert 2006: 233) — with lexical listing as a monomorphemic stem; and (ii) (re)analysis of the stem as unaccented, thereby triggering the application of ADA. The factors motivating these innovations are discussed in 4.2.1 for hūške- and in 4.2.2 for the nasal-infix verbs.

\subsubsection{Hitt. hū̌ške- and ADA}

All previous analyses of Hitt. hǚške- 'wait' agree on at least one point: on semantic grounds, it cannot be synchronically derived from the cognate simplex verb huiš- 'live' (< PIE ${ }^{*} h_{2}$ wes-). ${ }^{46}$ While other -ške- verbs are semantically compositional, exhibiting only aspectual differences with respect to their verbal base, the much greater divergence of hüške- suggests that it has undergone semantic specialization, developing a new meaning uniquely associated with the historical *-ské- formation.

Could this semantic divergence have been the catalyst for prosodic change in hūške-? This possibility is raised by the recent work of Probert (2006), who argues that functional considerations may increase the likelihood of a word undergoing the historical process she has termed "demorphologization"-in effect, a subtype of lexicalization that occurs when learners fail to acquire the constituent structure of a morphologically complex word (cf. 5.1). From her analysis of Greek thematic adjectival suffixes (e.g. -pó-), Probert (2006: 286) concludes that "a stem formed with one of these suffixes may come to be treated synchronically as monomorphemic if, for some formal or functional reason, the word loses its connection with a synchronically clear category of words

45 Under this analysis, the corresponding plural forms must be attributed to secondary developments (cf. nn. 20, 43).

46 Kloekhorst (2008: 365 ) calls it a "petrified imperfective", while it is labelled a "hidden iterative" by Puhvel (1991: 410-411), who adduces the parallel semantic development of Ved. vas- 'dwell' and Toch.B. wäs- 'id.' 
containing the suffix." In the case of huuške-, then, increasing semantic opacity between the verb and its derivational base may have provided the "functional" motivation for demorphologization.

Yet the result of this process need not have been prosodic change-at least not immediately. When hǚske- ceased to be perceived as the imperfective of an existing verbal base due to semantic drift, its new meaning 'wait' was stored in an independent lexical entry. After demorphologization, the phonological representation associated with this entry must have contained the basic segmental content of its surface representation at the time of reanalysis, while lacking any morpheme boundari(es) associated with its derivational prehistory; less certain, however, would have been its accentual properties-i.e. */Huske-/ or */Huské-/. At the crucial stage at which morphological acquisition failed, veridical production of the previous generation's surface form *Huské-, whose ICTUS was due to the accented suffix */-ske-/, would entail lexical listing of monomorphemic */Huské-/ with peninitial accent. If such listing were to occur, then demorphologization would not yield any directly detectable change: the new generation of PA (or pre-Hittite) speakers would continue to produce *Huské-, even though they had innovative underlying representations.

But an alternative scenario also finds support in the history of Greek; according to Probert (2006: 258), "a possible, but not inevitable, consequence" of demorphologization "is the loss of a non-default accent and its replacement with the default accent for the language." This "reversion to default" - in Greek, "recessive accentuation" - would follow straightforwardly if the newly monomorphemic stem were instead listed without lexical accent, or subsequently came to lose this property. Why some words acquire (and retain) lexical accent but other words do not likely depends on to a multiplicity of incompletely understood factors, yet one clearly established by Probert (2006) is the role of token frequency: highly frequent lexical items tend to resist the shift to default accentuation, even though they exhibit the other features characteristic of demorphologized formations, ${ }^{47}$ and conversely, relatively infrequent items with these features strongly tend to adopt the default pattern.

47 Such as non-prototypical semantics for the word's (historical) morphological category. A likely example of a high-frequency word retaining non-initial ICTUs despite demorphol-

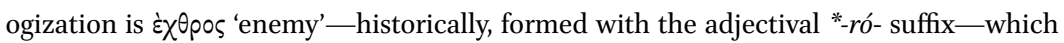
occurs more than $500 \times$ in Greek between Homer and the 2nd c. CE; see Probert (2006: 232-233) for discussion. 
Probert's findings suggest that when a word ceases to be parsed as morphologically complex, preservation of non-default ICTUS via lexical listing occurs only when learners have been exposed to significant positive evidence-i.e. many tokens — of that accentual pattern. ${ }^{48}$ The implications of this result for a relatively low-token frequency word like Hittite hūške-, which is attested less than $10 \times$ in the entire corpus, seem clear: it is very likely that learners underexposed to the inherited surface form *Huské- would eventually have converged on an unaccented stem that consequently came under the domain of ADA; the assignment of default leftmost ICTUS yielded (in the 2nd person singular) *Húskesi, which developed into the attested form (1c) hūuškeši.

The development of Hitt. hǚske- may thus be schematized as in (22):

$$
\begin{aligned}
& \text { (22) Stage I */Hwes - ské -si/ } \rightarrow \text { *Huskési 'you live' (impfv.) } \\
& \text { (Stage II) */Huské - si/ } \rightarrow \text { *Huskési 'you wait' } \\
& \text { Stage III */Huske-si/ } \rightarrow \text { *Húskesi 'you wait' (via ADA) } \\
& \text { > Hitt. hūšskeši }
\end{aligned}
$$

Stage I is the inherited situation, the suffix *-ské- deriving an imperfective stem from the verbal root of Hitt. huišs- live'. Stage II represents a potential intermediate stage at which demorphologization has occurred, and the accentual properties of the surface form lexicalized; the actual surface forms would not change at this stage, but their underlying forms do. At Stage III-the synchronic situation in Hittite - the stem has become unaccented, and receives leftmost ICTUS by default.

Demorphologization and loss of underlying accent thus provide an explanation for the historically (and synchronically) unexpected leftmost ICTUS of Hitt. hūške-. While it may seem uneconomical to posit so much machinery to explain a single attested form, 4.2.2 will show that the same basic tools can motivate the similarly problematic initial ICTUS in PA nasal-infix verbs.

\subsubsection{PA Nasal-Infix Verbs and ADA}

The innovative leftmost ICTUS observed in Anatolian nasal-infix verbs is consistent with the application of ADA, yet as was the case for hūške-, it is unclear why these formations should fall under the domain of this default principle. Vedic Class VII and Class IX presents support the reconstruction of an accented infix /-né-/ for PIE (cf. 2.1); thus if the Anatolian nasal-infix verbs were synchronically derived according to the inherited pattern, ADA would have been

48 See 5.1 below for further discussion of these issues. 
"blocked" by the underlying accent of the infix, which would preferentially receive the ICTUS.

Understanding how the ADA may have come to apply to Anatolian nasalinfix verbs begins with a better understanding of their attestation and how these formations are situated within the Anatolian verbal system. Ablauting nasal-infix presents are continued only in Hittite and Palaic šüna-, the other Anatolian languages showing no trace of the full-grade infix. This restricted distribution suggests that nasal-infix verbs were a closed morphological class already in Proto-Anatolian. Moreover, it seems likely that membership in this class was shrinking: not only do nasal-infix verbs disappear in the other Anatolian languages, but their historical loss is paralleled by diachronic trends within (pre-)Hittite, where inherited nasal-infix verbs have been renewed or replaced in several different ways. One clear example of such renewal is Hitt. šunnai 'fills', which must have secondarily acquired hi-verb inflection in the prehistory of Hittite, since the original mi-verb is directly reflected in Palaic šünat (cf. n. 24 above). This development suggests a pattern whereby original nasalinfix presents were remade as hi-verbs, and this process can in fact be observed within the attested period of Hittite, as the mi-verbs cited in $(3 \mathrm{~d}-3 \mathrm{e})$ give way to innovative zinnai (e.g. КU 6.45 iv 45), duwarnai (KBo 39.8 ii 11), and hullai (KBo 6.29 iii 43).49

Nasal-infix presents that resisted these analogical pressures may have been subject to replacement by other means. Hitt. harnink- 'destroy', attested already in Old Script texts (e.g. harnikta; KBo 22.2 Vo 15), begins to face competition in New Hittite from semantically identical harg(a)nu- 'id.' (KBo 6.28 Ro 7), derived via $n u$-suffixation from the intransitive verbal stem hark- 'die'. In contrast to nasal infixation, $n u$-suffixation is highly productive both in (23a) Hittite and $(23 \mathrm{~b})$ Luwian $^{50}$ the suffix freely attaches to verbal, adjectival, and even nominal bases to form new transitive or causative predicates (cf. Luraghi 2012).

(23) a. Hitt. ling(a)nu- 'make swear' : link- 'swear' :

Hitt. pahh $(a)$ šnu- 'protect' : $\operatorname{panhh}_{2}(a)$ š- 'protect'

Hitt. parkunu- 'purify' : parkui- 'pure'

Hitt. ešharnu- 'bloody' : ēšhar- 'blood'

49 As Kloekhorst (2008: 140, passim) has observed, this inflectional type is productive within Hittite.

$5^{0}$ It is possible that Lydian verbal stems in -no-/-vo- also contain the same suffix; see Oettinger (1978: 77) and Melchert (1992b: 52). 
b. CLuw. huinu- 'cause to run' : hui(ya)- 'run'

HLuw. (CRUs) tanu(wa)- 'cause to stand' : ta- 'stand'

CLuw. halalannu-šša- 'purify' : halāl(i)- 'pure'

CLuw. āšharnu- 'bloody' : āšnar 'blood'

The formal and functional agreement between these Hittite and Luwian $n u$ suffixal derivatives all but guarantees the productivity of this derivational process in PA, which in turn increases the likelihood that the Hittite-internal renewal of older harni $(n) k$ - by younger $h \arg (a) n u$ - reflects a type of replacement occurring already at a much earlier stage.

Two mechanisms whereby inherited nasal-infix presents were lost in Anatolian have therefore been identified: conversion into hi-verbs; and replacement by $n u$-suffixal derivatives. These prehistoric developments offer a plausible explanation for the nearly wholesale elimination of inherited nasal-infix formations in the Anatolian languages, and furthermore, call into question the status of the handful of attested forms in Hittite and Palaic - are they synchronically derived or lexicalized?

If the derivational analysis is correct, two questions present themselves: from what are the Anatolian nasal-infix verbs derived, and what is their function? Clackson (2007: 153) has called attention to the preponderance of reconstructible (perfective) root aorists beside (imperfective) nasal-infix presents, which may suggest that at some stage of PIE nasal infixation was used to derive atelic verbal stems from lexically telic roots. ${ }^{51} \mathrm{~A}$ trace of this PIE lexical aspect-based derivational relationship may be preserved in the etymological relationship between Hitt. huek- 'slaughter' and hüni(n)k- 'batter' (< * $h_{2}$ weg-; cf. $L I V^{2}: 286-287$ ), which have become semantically divorced by the time of Hittite. ${ }^{52}$ The relic status of this single pair ensures that this function of nasal infixation cannot have been maintained synchronically in Anatolian.

$5^{1} \quad$ Telicity is here understood to be a feature of lexical aspect, while perfectivity pertains to grammatical aspect; on the distinction, see (e.g.) Bertinetto (2001). If nasal infixation ever operated on grammatical aspect in PIE, this function could not have survived the Anatolian reorganization of the verbal system along fundamentally temporal lines.

$5^{2}$ It is extremely unlikely on semantic grounds that a derivational relationship held between hūni(n)k- and huek- synchronically in Hittite or even late PA. This assessment coincides with the judgment of Kloekhorst (2008: 348, 363), who lists the verbs under separate lemmata, and of Puhvel (1991: 381-382), who notes a "palpable semantic discrepancy" between the two. 
Another possible function of Anatolian nasal infixation is suggested by a number of cognate formations across the daughter languages that appear to reflect a transitivity opposition in PIE between intransitive simplex root formations and transitive (or causative) derived nasal-infix verbs (cf. Meiser 1993). ${ }^{53}$ This transitivizing function of nasal infixation is reflected in Hittite in the two additional etymological pairs in (24):

(24) a. ištarni( $n) k$ - 'cause to be sick' : ištark- 'ail; be(come) sick'

b. harni(n)k-'destroy' : hark- 'die' ( $\Rightarrow$ harg $(a) n u-' d e s t r o y ')$

While these two pairs are perhaps the strongest candidates for synchronic derivation at any stage in Anatolian, they nevertheless constitute a limited basis on which to assume that nasal infixation remains operative in late PA. Moreover, as a transitivizing strategy, nasal infixation would compete directly with productive $n u$-suffixation (cf. Luraghi 2012: 8-9), whose derivatives are being extended in PA at the expense of old nasal-infix formations as evident in $(24 \mathrm{~b}) \cdot{ }^{54} \mathrm{At}$ best, then, the Hittite evidence in (24) provides weak support for the derivational account. ${ }^{55}$

However, the main problem with this account is the fact that, for the majority of Anatolian nasal-infix verbs, the nasal-infix verb itself is the only evidence for the etymological root from which it was historically derived. The inherited PIE root (aorist) formations that once provided language learners with direct evidence for these verbal roots have been lost in PA; thus learners in late PA would (somehow) first need to extract these roots from their corresponding nasal-infix verbs in order to derive these verbs via nasal infixation. ${ }^{56}$ The acqui-

53 This semantic opposition is nicely preserved in derivatives of the root " $p l e h_{1}$ - 'become full' (cf. $L I V^{2}: 482-483$ ): the transitive nasal-infix present is directly reflected in Ved. prṇáti 'fills', and the original intransitive root aorist continued in Hom. Gk. $\pi \lambda \hat{\eta} \tau 0$ 'was filled'. See also Clackson (2007: 154).

54 It should be noted also that, at least at an early stage, the function of nasal infixation in (24a) and in (24b) would not have been strictly parallel. Since the original meaning of ištark- was likely 'ail, afflict' with accusative experiencer, nasal infixation would not have changed the argument structure of the base verb in the same way as hark- 'die', where the experiencer is nominative (cf. Luraghi 2010: 253-257; Puhvel 1984: 475-477). Further arguments to this end are presented in 5.1.

$5^{6}$ Byrd (2015:138) suggests the intriguing possibility that nasal-infix presents were synchronically derived from root aorists in PIE (cf. Clackson 2007: 154). This assumption would provide an even more straightforward account of the loss of nasal infixation as a synchronic process in PA, as it would require only that the inherited root formations cognate with the Anatolian nasal-infix verbs were lost. 
sition of nasal infixation under such circumstances would thus be extremely difficult, if possible at all. ${ }^{57}$

In view of these formal and functional issues, the derivational analysis of nasal-infix verbs in late PA is unsustainable. A more plausible alternative is that, as their cognate verbal root formations were gradually lost, historical nasalinfix verbs underwent demorphologization and were lexicalized as monomorphemic stems. These developments made the derivational process itself increasingly opaque, and eventually, there was insufficient positive evidence for PA language learners to acquire it at all; as a result, nasal-infix verbs ceased to be processed as a derived morphological category, and historical members of this category — even those with existing cognate root formations-were individually lexically listed. ${ }^{58}$

Once lexicalized, historical nasal-infix verbs became highly susceptible to the influence of productive neighboring morphological categories, which in some cases led to their analogical remodeling as hi-verbs or lexical replacement by functionally equivalent $n u$-suffixal derivatives. ${ }^{59}$ Those inherited nasal-infix verbs that escaped these processes and are attested in Hittite and Palaic accordingly came to have the newly monomorphemic PA underlying forms in (25):60
(25) ${ }^{*} /$ Huneg-/ 'batter'
*/durn̄̄-/ 'break'
*/hrneg-l
*/ninek-/ 'mobilize'
*/Hullǣ-/ 'fight'
*/strneg -1
*/tinǣ-/ 'finish'
*/sunō-/ 'fill'
*/srneg-1

57 Hawkins and Cutler (1988: 309-310) argue that nasal infixation is cross-linguistically disfavored precisely because it is difficult to process morphologically.

$5^{8}$ As discussed in 4.2.1, Probert (2006: 286) has identified the loss of a "connection with a synchronically clear category of words containing the suffix" as a significant factor in demorphologization. This systematic demorphologization of nasal-infix verbs would thus constitute an extreme case of this phenomenon, i.e. driven by the loss of the morphological category itself. As an anonymous reviewer points out, historical nasal-infix presents in PDE (e.g. stand) are synchronically irregular, and so must similarly be lexically listed on an item-by-basis.

59 The demorphologization/lexicalization analysis provides natural motivation for the development of $h \arg (a) n u$ - in New Hittite. When older harni $(n) k$ - was lexicalized as a simplex stem, it left behind a morphological gap for a compositional causative (i.e. CAUSE + DIE) to hark-, which was therefore filled by productively derived harg $(a) n u-$.

6o Cf. (16) above. For the reconstruction of the roots of Hitt. harni(n)k-, šarni $(n) k$-, and ištarni $(n) k$-, see $L I V^{2}: 725^{-728}$, and on the phonologization of the non-etymological nasal in these forms, see Shatskov (2006) (cf. Hart 1977). 
(25) shows that the old morpheme boundary between nasal-infix and root is no longer present, and the historical infix no longer accented. Just as for hüške- 'waits' (cf. 4.2.1), accentual change may not have been immediate; yet it is hardly surprising that, dissociated from any well-defined morphological class already in the prehistory of Hittite and Palaic, these verbs are attested with only leftmost ICTUS, ${ }^{61}$ which was shown in 3.3 to derive via ADA from underlying representations that are disyllabic, monomorphemic, and-above all-unaccented. ${ }^{62}$

A synopsis of the proposed diachronic trajectory of Proto-Anatolian nasalinfix verbs as applied schematically to Hitt. huunikzi 'batters' is presented in (26):

$$
\begin{aligned}
& \text { (26) Stage I */Hwe - né-g-ti/ } \rightarrow{ }^{*} H u n e ́ k t i ~ ' b a t t e r s ' \\
& \text { (Stage II) */Hunég - ti/ } \rightarrow{ }^{*} H u n e ́ k t i ~ ' b a t t t e r s ' \\
& \text { Stage III */Huneg - ti/ } \rightarrow{ }^{*} \text { Húnekti 'batters' (via ADA) } \\
& \text { > Hitt. hūnikzi }
\end{aligned}
$$

During the first stage, Proto-Anatolian faithfully preserves the morphological pattern of deriving nasal-infix verbs inherited from Proto-Indo-European. Increasing formal and functional opacity of the derivational relationship between nasal-infix verbs and their derivational bases in PA then triggers demorphologization and lexicalization. This process may have involved lexical listing of peninitial accent, yielding the new Stage II grammar that would generate the same surface forms as at Stage I. Yet if the accent was lexicalized on the historical infix, it was subsequently lost prior to the earliest attested record, leading to the application of ADA and consequent leftmost ICTUS in the strong stem of all Anatolian nasal-infix verbs.

\section{Implications of Anatolian Default Accentuation}

The problem posed at the outset of this paper concerned a set of morphologically disparate Anatolian forms unified only by a single characteristic feature, viz. a historically unexpected and not yet satisfactorily explained leftmost

$61 \quad$ See 5.1 below for further discussion of these issues.

62 It is conceivable, however, that the relatively frequent historical nasal-infix verbs in -ni(n)k- (i.e. harni $(n) k$-, šarni $(n) k$-, and ištarni $(n) k$-) have remained at Stage II (viz. with lexically listed accent); yet as pointed out in 2.2.1, it cannot be determined whether these verbs have peninitial (= Stage II) or initial (= Stage III) ICTUS in the strong stem. 
ICTUS that appears to be "retracted" from its PIE position. Since this prosodic innovation cuts across morphological lines, the affected forms do not readily submit to analogical explanation, nor can a putative connection between epenthesis and ICTUS "attraction" - even if this analysis could be maintained (cf. 2.4) - generalize to all examples of this phenomenon. However, these forms are all consistent with the application of ANATOLIAN DEFAULT ACCENTUATION, which functions to assign ICTUs to the leftmost syllable of a prosodic word when no accented morphemes are present (3.3). The operation of this default principle explains the striking fact that, when Anatolian departs from inherited accentual patterns, the ICTUS regularly surfaces on the leftmost syllable and not elsewhere.

4 aimed to address a more complex question: Why do these words lack accented morphemes and so come under the domain of ADA? It was proposed that the ADA applies to Hittite forms like (1d) punušzi and (1e) teripzi because they are based on unaccented roots: when epenthesis induces a change in their phonological shape, the same accentual principles assign ICтUs to a historically-new position (4.1). In contrast, the historical nasal-infix verbs and (1c) hüšske- once contained an accented derivational morpheme, but their dissociation from productive morphological categories resulted in restructuring of their underlying representations - viz. demorphologization and loss of accentedness - and accordingly, the assignment of default leftmost ICTUs by $\operatorname{ADA}(4.2) \cdot{ }^{63}$

The remainder of this paper briefly considers some implications of this analysis for the diachrony of Anatolian accentuation as well as the development of lexical interface systems more broadly. 5.1 takes up some theoretical issues raised in 4.2 pertaining to demorphologization, examining in greater detail the causes and consequences of this diachronic phenonemenon. 5.2 discusses the inheritance of default accentuation, and considers its potential to introduce prosodic change. Finally, in 5.3 the significance of the Anatolian evidence for PIE prosody is assessed.

63 It should be noted, however, that the analysis advanced here is not the only one compatible with the Anatolian data; e.g. PA *Húnekti is also compatible with an underlying form /Húneg - ti/ with lexically listed accent on the first syllable. Thus while I have presented arguments in favor of ICTUS assignment via ADA, determining the "best" analysis-viz. in terms of explanatory power, economy, psycholinguistic and typological plausibility, etc.-will require much further research on the Anatolian languages as well as crosslinguistically. 


\subsection{Causes and Consequences of Demorphologization}

4.2 introduced demorphologization-the diachronic loss of morphological structure - as a mechanism for prosodic change at the word level in lexical interface systems. Two pertinent questions will be considered further here: (i) What factors trigger demorphologization?; and (ii) Why does it often lead to the loss of lexical accent, thereby yielding prosodic change?

Probert (2006) has proposed that demorphologization is induced by changes that render a word's formal or functional connection to its morphological category less transparent. Her diachronic study of Ancient Greek provides empirical support for this hypothesis to which may now be added the Anatolian data considered here. In particular, the development of Hitt. hūške- 'wait', semantically opaque with respect to its historical base (cf. huišs- 'live'), finds a natural explanation under Probert's hypothesis. Demorphologization may thus be understood to affect words on an item-by-item basis, which over time may result in the appearance of a categorical phenomenon, as in the Anatolian nasal-infix verbs. Demorphologization in this type can be attributed to a kind of formal opacity: the relationship between nasal-infix verbs and their derivational bases could no longer be understood by learners who did not have the latter in their lexicon; consequently, at least some of these inherited nasal-infix verbs were lexicalized, and so outlived their cognate root formations. Finally, as evidence for the derivational pattern itself dwindled, even nasal-infix verbs whose historical bases survived in Anatolian were eventually subject to demorphologization and lexicalization; thus from a synchronic perspective, the relationship in Hittite between harni(n)k- 'destroy' and hark- 'die' is purely semantic, just as is the case for set and sit in PDE.

While identifying more cases of demorphologization will no doubt shed further light on this question, Probert's hypothesis is further recommended by a substantial body of psycholinguistic research that suggests a plausible cognitive basis for this development. ${ }^{64}$ Dual-route race models of morphological processing (e.g. Schreuder and Baayen 1995) distinguish between two types of lexical access: (i) the parsing route, whereby a word is parsed into its constituent morphemes and accessed by way of these parts; and (ii) the direct route, whereby a word is accessed holistically via its own lexical representation. Morphologically complex words initiate a simultaneous attempt at processing by both routes, which then "race" to compute and deliver an interpretation. Factors generally considered relevant to determining the "winner" include the word's frequency, its phonological and semantic transparency, and the produc-

64 For a recent survey of this literature, see Diepandaele et al (2012). 
tivity of the affixes it contains (cf. Schreuder and Baayen 1995; Hay and Baayen 2002).

Interestingly, experimental studies have confirmed that some of the same factors identified as causes of demorphologization also facilitate direct route access. For example, it has been repeatedly shown that PDE complex words like re-lease, depart-ment, or dis-patch, which are phonologically segmentable into base plus affix but not semantically compositional, do not prime these bases (Marslen-Wilson et al 1994; cf. Rastle et al 2000). This result has generally been taken to indicate that, in processing a semantically opaque complex word, the lexical representation ostensibly shared with its base remains unactivated, a fact which points in turn to holistic word access by the direct route.

Other studies have shown that processing is sensitive to such factors as productivity and frequency. Hay and Baayen (2002) have demonstrated a robust correlation between parsing and productivity: productive affixes, which are regularly extended to new words, strongly tend to be parsed, ${ }^{65}$ while nonproductive affixes are associated with direct access. In addition, when the frequency of a derived word exceeds that of its base, it is likely to be processed holistically regardless of its absolute frequency; thus it is highly probable that PDE verbs like un-leash or re-iterate, which are significantly more frequent than their verbal bases leash and iterate, will be accessed directly (Hay 2001). Indeed, one might question whether any synchronic formal connection is perceived between re-iterate and iterate by many PDE speakers, since the latter word is so marginal that some (or even most) speakers may be unaware of it. The same question might be posed of nasal-infix verbs in late PA, a closed class in which, for the majority of items, the derivational no longer exists independently or is so rare as to be entirely unattested.

The fact that many of the same factors - transparency, productivity, and (relative) frequency ${ }^{66}$ - are involved in both demorphologization and holistic processing suggests that demorphologization may be viewed as the lexicalization of a diachronically increasing tendency for words to be processed in this way. ${ }^{67}$ If so, demorphologization is both empirically founded and cognitively

65 Hay and Baayen (2002) argue that productivity is a function of parsing and parsability; affixal productivity is maintained as a direct consequence of being frequently parsed.

66 Probert (2006: 292, passim) has demonstrated a correlation between absolute frequency and demorphologization, but the role of the relative frequency of derivative and base remains to be investigated.

67 Note that demorphologized words no longer activate the affixes they historically contained, thus decreasing the productivity of the affix and increasing the probability that other words containing it will eventually undergo demorphologization (Hay and Baayen 2002). 
motivated. It remains unexplained, however, why words that undergo demorphologization tend to become subject to default accentuation, as appears to be the case in both Ancient Greek and Anatolian. In these languages which are abundant in lexical contrasts, why aren't their accentual patterns simply lexicalized?

Once again, this issue will be elucidated by further research, yet it is significant that in the data examined by Probert (2006: 233), retention of a nondefault accentual pattern (i.e. Stage II) is the exception rather than the rule: "resistance to accentual regularization after the loss of synchronic analysis" is shown to be a feature characteristic only of highly frequent lexical items. In a similar vein, the Anatolian cases of demorphologizaton considered here offer no compelling evidence for lexicalization of accent following demorphologization (though cf. n. 62). These findings suggest that, at least in these languages (cf. 5.2), learners posit accentedness as a feature of morphemes only in response to significant positive evidence for accented behavior in a variety of morphophonological contexts. Because (productive) derivational and inflectional suffixes occur frequently by both type and token, their properties are relatively easily learned and thus diachronically stable. However, only the most frequent demorphologized stems-historically, the combination of a root and a particular morpheme, and so necessarily less frequent than that morpheme - will provide sufficient evidence for their underlying accent to be maintained across generations of speakers; and even these words, if their frequency at any point dips below some critical threshold, are liable to the application of default ICTUS assignment. ${ }^{68}$

\subsection{The Diachrony of Default Accentuation and Prosodic Change}

The analysis developed in 1-3 of the Anatolian data-in particular, of historically unaccented roots, which in 4.1 were argued to be subject to ADA both before and after inner-Anatolian epenthesis-requires that the same principle of default accentuation was a synchronic feature of Anatolian grammar at distinct prehistoric stages. Its application at each stage implies that default accentuation may be diachronically stable, and even suggests that, like other

68 The diachrony of demorphologized words may be profitably compared to that of loanwords, since they too lack morphological structure in the borrowing language, and often enter it with exceptional accentuation that reflects the phonology of the donor language. In contrast to demorphologization, which has been little studied, it is well known that loanwords over time tend to adopt the default accentual pattern of the borrowing language; see (e.g.) Svensson and Hering (2009) on the development of French loanwords in the history of English. 
synchronic phonological rules, ${ }^{69}$ its successful intergenerational transmission is the unmarked case.

If so, it is to be expected that ADA is also operative synchronically in Hittite and the other Anatolian languages. While the Anatolian forms assessed here may all be ascribed to its prehistoric operation, there is nevertheless preliminary support for this hypothesis. Some suggestive evidence comes from Luwian, where ADA may explain the "retracted" leftmost ICTUs in the generalized weak verbal stems of Cuneiform Luwian tūwa- 'put' and pìya- 'give' (cf. Melchert 1994: 89). This generalization must be post-PA, since Hittite preserves the original ablauting paradigm in each case (3rd s. dāi 'places'; $p \bar{a} i$ ' 'gives'), and so too, then, must be the innovation of leftmost ICTUS in these Luwian forms. Yet likely even more significant in this respect are Hittite simplex mi-verbs, whose strong stem in PA received ICTUS via ADA (4.1.2). Since Hittite recapitulates inherited accentual patterns in this morphological category, it is reasonable to assume that the corresponding Hittite forms are also synchronically subject to ADA. Taken together, this evidence is highly encouraging, although a more systematic, synchronic analysis must be left as a task for future research.

More broadly, the Anatolian evidence aligns with Ancient Greek in demonstrating how default accentuation can introduce prosodic change in lexical interface systems. While the default principle itself remains diachronically stable, ICTUs assignment may be disrupted by phonological developments that affect syllabic structure (e.g. epenthesis, deletion), or it may acquire new inputs due to processes like demorphologization. As more words come under the domain of default accentuation, purely phonological factors become increasingly reliable predictors of the ICTUS, which may eventually result in the nearly complete elimination of lexical accent. ${ }^{70}$

This trajectory is, of course, hardly inevitable, and some languages may instead tend to opt for lexicalization whenever the interaction of morphophonological change and default accentuation would yield new ictic patterns. ${ }^{71}$

69 Such as the familiar PIE "Double Dental Rule" - the rule of *s-epenthesis between heteromorphemic coronal stops-which is maintained from PIE through PA and into (at least) он and CLuw. (cf. Melchert, 1994: 49, 58, 109).

70 In fact, Halle (1997) has plausibly argued that the fixed initial ICтUs pattern that emerged in Germanic, Celtic, and the earliest stage of Italic was due to the loss of lexical accent and concomitant generalization of the PIE leftmost default principle (cf. 5.3). For similar arguments about the generalization of recessive accentuation in the Lesbian dialect of Ancient Greek, see Probert (2006: 143) (cf. Gunkel 2014).

71 Gunkel (2014) rightly observes the "trend in the diachronic development of the [Ancient] Greek accentual system ...from a relatively 'free' accent system, where accent was primar- 
Nevertheless, the agreement between Ancient Greek and Anatolian suggests that diachronic "reversion to default" is a more general feature of lexical interface systems. Further investigation of this tendency within the Indo-European languages and cross-linguistically thus may not only allow for the explanation of changes in word prosody that have resisted traditional analogical explanations in these languages, but also, by identifying such changes (or lack thereof), offer insight into why some languages seem to prefer default accentuation to lexicalization. A better understanding of this question would constitute a small step toward a predictive theory of prosodic change in lexical interface systems.

\subsection{ADA and the Reconstruction of PIE Prosody}

While lexical interface systems constitute a minority type cross-linguistically, the Indo-European languages - both ancient and modern - are very well represented among them. This distribution can hardly be a coincidence, and must instead reflect inheritance from PIE, where ICTUS assignment was determined synchronically by the interaction of the accentual properties of morphemes and phonological principles, including a principle of default ICTUS assignment. How, then, did this PIE default principle operate?

As noted in 3.1, Kiparsky and Halle (1977) have argued that accentuation in PIE was governed by the BAP, repeated below:

(9) BASIC ACCENTUATION PRINCIPLE (BAP):

If a word has more than one accented syllable, the leftmost of these gets the ICTUs. If a word has no accented syllable, the leftmost syllable gets the ICTUS.

Their reconstruction of the default component of the BAP was founded primarily on Vedic and Balto-Slavic; the evidence from these two branchesrecently reassessed by Kiparsky (2010, forthcoming) - is consistent with the synchronic operation of leftmost default ICTUS assignment, and thereby supports the reconstruction of this principle for their common ancestor. Leftmost default may also be indirectly continued in Ancient Greek, where recessive accentuation-shown convincingly by Probert (2006:128-144) to be the default pattern in the language-likely reflects this same principle in a slightly modified form, viz. leftmost within the accentable domain.

ily morphologically determined and phonology played a minor role ...to a less free, more phonologically constrained system." Yet this trajectory did not culminate in the loss of lexical accent: not only does Modern Greek have a stable lexical interface system, but it is even argued by Revithiadou (1999: 4, passim) that lexical accent is preferred in this system. 
Significantly, the Anatolian languages appear to provide an exact match for this default leftmost pattern. According to the analysis developed in 1-3, the pattern of ICTUs "retraction" observed in Hittite, Palaic, and Luwian is a direct consequence of the prehistoric operation of ADA. The reconstruction of ADA for PA (cf. 2.3) not only bolsters the case for Kiparsky and Halle's reconstruction, but projects this default leftmost pattern deeper into prehistory, situating its operation in high-node PIE - viz. the state of the proto-language prior to the separation of the Anatolian branch from the other ("core" or "nuclear") IndoEuropean languages. ${ }^{72}$ Any alternative account of PIE accentuation must now explain how the same default principle was innovated separately in four separate language branches - a situation that is, moreover, economically explained by diachronic retention. For the present, then, it is most plausible to assume that the phonological principle in (27) was synchronically operative in highnode PIE, and that, when no constituent morpheme of a prosodic word was lexically specified for accent, this principle functioned to assign ICTUs to its leftmost syllable.

\section{(27) PROTO-INDO-EUROPEAN DEFAULT ACCENTUATION:}

If a word has no inherently accented syllable, the leftmost syllable gets the ICTUS.

\section{References}

Alderete, John. 2001a. Morphologically Governed Accent in Optimality Theory. New York: Routledge.

Alderete, John D. 20o1b. Root-Controlled Accent in Cupeño. Natural Language \& Linguistic Theory 19(3).455-502.

Beekes, Robert S.P. 1985. The Origins of the Indo-European Nominal Inflection. Innsbruck: Innsbrucker Beiträge zur Sprachwissenschaft.

Bertinetto, Pierre Marco. 2001. On a frequent misunderstanding in the temporal-aspectual domain: the perfective-telic confusion. In Carlo Cecchetto, Gennaro Chierchia, and Maria T. Guasti (eds.), Semantic Interfaces: Reference, Anaphora, Aspect. Stanford, CA: CSLI Publications.

Blevins, Juliette. 1993. A tonal analysis of Lithuanian nominal accent. Language 69.237273 .

Byrd, Andrew M. 2015. The Indo-European Syllable. Leiden / Boston: Brill.

\footnotetext{
72 On this divergence, see most recently Chang et al (2015: 195-198).
} 
Caballero, Gabriela. 2011. Morphologically conditioned stress assignment in Choguita Rarámuri. Linguistics 49(4)·749-790.

Carruba, Onofrio. 1981. Pleneschreibung und Betonung im Hethitischen. Zeitschrift für vergleichende Sprachwissenschaft 95.232-248.

Chang, Will, Chundra Cathcart, David Hall, and Andrew Garrett. 2015. Ancestry-constrained phylogenetic analysis supports the Indo-European steppe hypothesis. Language 91(1).194-244. doi:10.1353/lan.2015.0005.

Chantraine, Pierre. 1968 [2009]. Dictionnaire étymologique de la langue grecque. Histoire des mots. Klincksieck, 2009 edn.

Clackson, James. 2007. Indo-European Linguistics: an Introduction. Cambridge / New York: Cambridge University Press, illustrated, reprint edn.

Diepandaele, Kevin, Jonathan Grainger, and Dominiek Sandra. 2012. Derivational Morphology and Skilled Reading. In Michael J. Spivey, Ken McRae, and Marc F. Joanissse (eds.), The Cambridge Handbook of Psycholinguistics, 311-332. Cambridge, UK / New York: Cambridge University Press.

Eichner, Heiner. 1978. Die urindogermanische Wurzel * ${ }_{2}$ reu-. Die Sprache 24.144-162.

Eichner, Heiner. 1986. Neue Wege im Lydischen I: Vokalnasalität vor Nasalkonsonanten. Zeitschrift für vergleichende Sprachforschung 99.203-219.

Eichner, Heiner. 1988. Anatolisch und Trilaryngalismus. In Alfred Bammesberger (ed.), Die Laryngaltheorie und die Rekonstruktion des indogermanischen Laut-und Formensystems, 123-151. Heidelberg: Winter.

Eichner, Heiner. 1992. Anatolian. In Jadranka Gvozdanović(ed.), Indo-European Numerals, 29-96. Berlin / New York: de Gruyter.

Fortson, Benjamin W. 2010. Indo-European Language and Culture. Oxford, U. K. / Malden, MA: Wiley-Blackwell, 2 edn.

Gunkel, Dieter. 2014. Accentuation. In Encyclopedia of Ancient Greek Language and Linguistics. Leiden: Brill.

Güterbock, Hans G. and Harry A. Hoffner (eds.). 1997. The Hittite Dictionary of the Oriental Institute of Chicago: Volume $L-N$. Chicago: The Oriental Institute of the University of Chicago.

Hall, Nancy. 2011. Vowel Epenthesis. In Marc Van Oostendorp, Colin J. Ewen, Elizabeth Hume, and Keren Rice (eds.), The Blackwell Companion to Phonology, 1576-1596. Oxford / Malden, MA: Wiley-Blackwell.

Halle, Morris. 1973. The accentuation of Russian words. Language 49.312-348.

Halle, Morris. 1997. On Stress and Accent in Indo-European. Language 73.275-313.

Halle, Morris and Paul Kiparsky. 1979. Internal Constituent Structure and Accent in Russian Words. In Ernest A. Scatton, Richard D. Steele, and Charles E. Gribble (eds.), Studies in Honor of Horace G. Lunt, 128-153. Bloomington, IN: Slavica.

Hart, Gillian R. 1977. On the Origin of Hittite Nasal Infix Verbs of the Type šarnikzišarninkanzi. Archivum Linguisticum 8(2).133-141. 
Hart, Gillian R. 1980. Some observations on plene-writing in Hittite. Bulletin of the School of Oriental and African Studies 43.1-17.

Hawkins, John A. and Anne Cutler. 1988. Psycholinguistic Factors in Morphological Asymmetry. In John A. Hawkins (ed.), Explaining Language Universals, 280-317. Oxford: Blackwell.

Hay, Jennifer. 2001. Lexical Frequency in Morphology: Is Everything Relative? Linguistics 39.1041-1070.

Hay, Jennifer and R. Harald Baayen. 2002. Parsing and Productivity. In Geert Booij and Jaap van Marle (eds.), Yearbook of Morphology 20o1, 203-235. Dordrecht: Kluwer.

Hill, Jane H. 2005. A Grammar of Cupeño. Los Angeles / Berkeley, CA: University of California Press.

Hyman, Larry. 2006. Word prosodic typology. Phonology $2.225-257$.

Kavitskaya, Darya. 2001. Hittite Vowel Epenthesis and the Sonority Hierarchy. Diachronica $18(2) .267-299$.

Kim, Ronald I. 2013. Metrical grid theory, internal derivation and the reconstruction of PIE nominal accent paradigms. In Götz Keydana, Paul Widmer, and Thomas Olander (eds.), Indo-European Accent and Ablaut. Copenhagen: Museum Tusculanum Press.

Kimball, Sara. 1983. Hittite Plene Writing. Ph.D. thesis, University of Pennsylvania.

Kimball, Sara. 1999. Hittite Historical Phonology. Innsbruck: Institut für Sprachwissenschaft der Universität Innsbruck.

Kiparsky, Paul. 1967. A propos de l'histoire de l' accentuation du grec ancien. Langages 8.73-93.

Kiparsky, Paul. 1973. The Inflectional Accent in Indo-European. Language 49(4).794849.

Kiparsky, Paul. 1982. The Vedic and Pāninian Accent Systems. In Some Theoretical Problems in Pānini’s Grammar, 55-76. Poona, India: Bhandarkar Oriental Research Institute.

Kiparsky, Paul. 1984. Lexical Phonology of Sanskrit Word Accent. In Shivram D. Joshi (ed.), Amrtādhāra: R.N. Dandekar Felicitation Volume, 201-210. Delhi: Ajanta Publications.

Kiparsky, Paul. 2003. Accent, Syllable Structure, and Morphology in Ancient Greek. In Elizabeth M. Athanasopoulou (ed.), Selected Papers from the 15th International Symposium on Theoretical and Applied Linguistics. Festschrift for Prof. Alexander Gogos, 81-106. Thessaloniki: University of Thessaloniki.

Kiparsky, Paul. 2010. Compositional vs. Paradigmatic Approaches to Accent and Ablaut. In Stephanie W. Jamison, H. Craig Melchert, and Brent Vine (eds.), Proceedings of the 21st Annual UCLA Indo-European Conference, Los Angeles, October 30-31, 2009, 137181. Bremen: Hempen.

Kiparsky, Paul. forthcoming. Accent and Ablaut. In Andrew Garrett and Michael Weiss 
(eds.), Handbook of Indo-European Studies. Oxford / New York: Oxford University Press.

Kiparsky, Paul and Morris Halle. 1977. Towards a Reconstruction of the Indo-European Accent. In Larry Hyman (ed.), Studies in Stress and Accent, 209-238. Los Angeles: University of Southern California Press.

Kloekhorst, Alwin. 2007. The Hittite Syllabification of PIE ${ }^{*} C u R$ and $K^{w} R$. In Detlev Groddek and Marina Zorman (eds.), Tabula Hethaeorum: Hethitologische Beiträge Silvin Košak zum 65. Geburtstag, 455-457. Wiesbaden: Harrassowitz.

Kloekhorst, Alwin. 2008. Etymological Dictionary of the Hittite Inherited Lexicon. Leiden / Boston: Brill.

Kloekhorst, Alwin. 2012. The phonological interpretation of plene and non-plene spelled $e$ in Hittite. In Benedicte N. Whitehead, Thomas Olander, Birgit A. Olsen, and Jens E. Rasmussen (eds.), The Sound of Indo-European: Phonetics, Phonemics and Morphophonemics, 243-262. Copenhagen: Museum Tusculanum Press.

Kloekhorst, Alwin. 2013. Indo-European nominal ablaut patterns: The Anatolian evidence. In Götz Keydana, Paul Widmer, and Thomas Olander (eds.), Indo-European Accent and Ablaut, 107-128. Copenhagen: Museum Tusculanum Press.

Kloekhorst, Alwin. 2014a. Accent in Hittite: A Study in Plene Spelling, Consonant Gradation, Clitics, and Metrics. Wiesbaden: Harrassowitz.

Kloekhorst, Alwin. 2014b. Once more on Hittite $\bar{a} / e$-ablauting hi-verbs. Indogermanische Forschungen $119 \cdot 55^{-77}$.

Kuiper, Franciscus B.J. 1942. Notes on Vedic Noun Inflexion. Medelingen der Koninklijke Nederlandse Akademie van Wetenschappen, Afdeling Letterkunde 5(4).161-256.

Kümmel, Martin J. 2007. Konsonantenwandel: Bausteine des Lautwandels und ihre Konsequenzen für die vergleichende Rekonstruktion. Wiesbaden: Reichert.

Luraghi, Silvia. 2010. Experiencer Predicates in Hittite. In Ronald Kim, Norbert Oettinger, Elizabeth Rieken, and Michael Weiss (eds.), Ex Anatolia Lux: Anatolian and Indo-European Studies in honor of H. Craig Melchert on the Occasion of his Sixty-Fifth Birthday, 249-264. Ann Arbor, M / New York: Beech Stave Press.

Luraghi, Silvia. 2012. Basic valency orientation and the middle voice in Hittite. Studies in Language 36(1).1-32.

Marslen-Wilson, William D., Lorraine K. Tyler, Rachelle Waksler, and Lianne Older. 1994. Morphology and Meaning in the English Mental Lexicon. Psychological Review 101(1).3-33.

Mayrhofer, Manfred. 1986-2001. Etymologisches Wörterbuch des Altindoarischen, vol. 13. Heidelberg: Winter.

McCarthy, John. 1997. Faithfulness and prosodic circumscription. Unpublished ms., University of Massachusetts, Amherst.

Meiser, Gerhard. 1993. Zur Funktion des Nasalpräsens im Urindogermanischen. In Gerhard Meiser (ed.), Indogermanica et Italica: Festschrift für Helmut Rix zum 65. Geburtstag, 280-313. Innsbruck: Institut für Sprachwissenschaft der Universität Innsbruck. 
Melchert, H. Craig. 1984. Studies in Hittite Historical Phonology. Göttingen:Vandenhöck \& Ruprecht.

Melchert, H. Craig. 1987. Reflexes of $h_{3}$ in Anatolian. Die Sprache 33.19-28.

Melchert, H. Craig. 1992a. Hittite Vocalism. In Onofrio Carruba (ed.), Per una Gramatica Ittita-Towards a Hittite Grammar, 181-196. Pavia: Gianni Iuculano.

Melchert, H. Craig. 1992b. The Third Person Present in Lydian. Indogermanische Forschungen $97 \cdot 31-54$.

Melchert, H. Craig. 1994. Anatolian Historical Phonology. Amsterdam / Atlanta: Rodopi.

Melchert, H. Craig. 2010. The Verbal Prefix "u-" and $<$ u > vs. $<$ ú $>$ Spellings in Anatolian Cuneiform. Paper presented at the 29th Annual East Coast Indo-European Conference, Ithaca, NY, 18-20 June 2010.

Melchert, H. Craig. 2013a. Ablaut Patterns in the Hittite hi-Conjugation. In Stephanie W. Jamison, H. Craig Melchert, and Brent Vine (eds.), Proceedings of the 24th Annual UCLA Indo-European Conference, Los Angeles, 26-27 October 2012, 137-150. Bremen: Hempen.

Melchert, H. Craig. 2013b. Hittite "Heteroclite" s-Stems. In Adam I. Cooper, Jeremy Rau, and Michael Weiss (eds.), Multi Nominis Grammaticus: Studies in Classical and IndoEuropean linguistics in honor of Alan J. Nussbaum on the occasion of his sixty-fifth birthday, 175-184. Ann Arbor / New York: Beech Stave Press.

Mester, R. Armin. 1994. The Quantitative Trochee in Latin. Natural Language and Linguist Theory 12.1-61.

Oettinger, Norbert. 1976. Indogermanisch * $s\left(h_{2}\right)$ neurr/n 'Sehne' und *(s)men- 'gering sein' im Hethitischen. Münchener Studien zur Sprachwissenschaft 35.93-103.

Oettinger, Norbert. 1978. Die Gliederung des anatolischen Sprachgebietes. Zeitschrift fürvergleichende Sprachforschung 92.74-92.

Oettinger, Norbert. 1979. Die Stammbildung des hethitischen Verbums. Nürnberg: Hans Carl.

Pedersen, Holger. 1926. La cinquième déclinaison latine. Copenhagen: A.F. Høst.

Poser, William John. 1984. The Phonetics and Phonology of Tone and Intonation in Japanese. Ph.D. thesis, Massachusetts Institute of Technology.

Prince, Alan. 1990. Quantitative consequences of rhythmic organization. In Karen Deaton, Manuela Noske, and Michael Ziolkowski (eds.), Proceedings of Chicago Linguistic Society 26: Papers from the Parasession on the Syllable in Phonetics and Phonology, 355-398. Chicago: Chicago Linguistic Society.

Prince, Alan and Paul Smolensky. 1993/2004. Optimality Theory: Constraint Interaction in Generative Grammar. Oxford / Malden, MA: Blackwell.

Probert, Philomen. 2006. Ancient Greek Accentuation: Synchronic Patterns, Frequency Effects, and Prehistory. Oxford / New York: Oxford University Press.

Puhvel, Jaan. 1984. Hittite Etymological Dictionary, Vol. 2: Words beginning with E and I. Berlin / New York: Mouton. 
Puhvel, Jaan. 1991. Hittite Etymological Dictionary, Vol. 3: Words beginning with H. Berlin / New York: de Gruyter.

Rastle, Kathleen, Matt H. Davis, William D. Marslen-Wilson, and Lorraine K. Tyler. 2000. Morphological and semantic effects in visual word-recognition: A time-course study. Language and Cognitive Processes 15(4/5).507-537.

Revithiadou, Anthoula. 1999. Headmost Accent Wins: Head Dominance and Ideal Prosodic Form in Lexical Accent Systems. Ph.D. thesis, Leiden University.

Rieken, Elisabeth. 2005. Zur Wiedergabe von hethitisch /o/. In Gerhard Meiser and Olav Hackstein (eds.), Sprachkontakt und Sprachwandel: Akten der XI. Fachtagung der indogermanischen Gesellschaft, Halle an der Saale, 17. bis 23 September 2000, 537549. Wiesbaden: Reichert.

Rix, Helmut. 1992. Historische Grammatik des Griechischen: Laut- und Formenlehre. Darmstadt: Wissenschaftliche Buchgesellschaft.

Rix, Helmut and M. Kümmel (eds.). 2001. Lexikon der indogermanischen Verben: Die Wurzeln und ihre Primärstammbildungen. Wiesbaden: Reichert, 2 edn.

Schindler, Jochem. 1972. L' apophonie des noms-racines. Bulletin de la Société de Linguistique de Paris $67 \cdot 31-38$.

Schindler, Jochem. 1975a. L' apophonie des thèmes indo-européens en -r/n-. Bulletin de la Société de Linguistique de Paris 70.1-10.

Schindler, Jochem. 1975b. Zum Ablaut der neutralen s-Stämme des Indogermanischen. In Helmut Rix (ed.), Flexion und Wortbildung: Akten der v. Fachtagung der Indogermanischen Gesellschaft, Regensburg, 9. bis. 14. September 1975. Wiesbaden: Reichert.

Schreuder, Robert and R. Harald Baayen. 1995. Modeling Morphological Processing. In Laurie Beth Feldman (ed.), Morphological Aspects of Language Processing, 131-154. Hillsdale, NJ: Erlbaum.

Shatskov, Andrew. 2006. Some remarks on Hittite infix verbs of the type harni $(n) k-$. Altorientalische Forschungen 33(2).286-292.

Svensson, Ann-Marie and Jürgen Hering. 2009. On the English and German Adaptation of French Loans in the Germanic Stress Pattern. Interdisciplinary Journal for Germanic Linguistics and Semiotic Analysis 14(1).85-100.

Čop, Bojan. 1970. Eine luwische orthographisch-phonetische Regel. Indogermanische Forschungen $85^{-96 .}$

Weiss, Michael. 2011. Outline of the Historical and Comparative Grammar of Latin. Ann Arbor / New York: Beech Stave Press.

Weiss, Michael. 2014. The PIE Laryngeals and the Name of Cilicia in the Iron Age. Paper presented at the 224th Meeting of the American Oriental Society, Phoenix, AZ, 14-17 March 2014.

Yates, Anthony D. 2014. On Proto-Anatolian Verbal Ablaut: The Hittite ašanzi-Type Reexamined. Paper presented at the Kyoto-UCLA Indo-European Workshop, Kyoto, 24-26 March 2014 (Handout available at https://ucla.academia.edu/AnthonyYates). 
Yates, Anthony D. forthcoming. Left But Not Leftmost? On the Interaction between Epenthesis and Ictus Assignment in Anatolian (Ms., https://ucla.academia.edu/ AnthonyYates). In Stephanie W. Jamison, H. Craig Melchert, and Brent Vine (eds.), Proceedings of the 26th Annual UCLA Indo-European Conference. Bremen: Hempen. Yoshida, Kazuhiko. 2010. Observations on the Prehistory of Hittite $i e / a$-Verbs. In Ronald Kim, Norbert Oettinger, Elizabeth Rieken, and Michael Weiss (eds.), Ex Anatolia Lux: Anatolian and Indo-European Studies in honor of H. Craig Melchert on the Occasion of his Sixty-Fifth Birthday, 385-393. Ann Arbor, MI / New York: Beech Stave Press. 